\title{
Drivers of atmospheric deposition of polycyclic aromatic hydrocarbons at European high-altitude sites
}

\author{
Lourdes Arellano $^{1}$, Pilar Fernández ${ }^{1}$, Barend L. van Drooge ${ }^{1}$, Neil L. Rose ${ }^{2}$, Ulrike Nickus ${ }^{3}$, Hansjoerg Thies ${ }^{4}$, \\ Evzen Stuchlík ${ }^{5}$, Lluís Camarero ${ }^{6}$, Jordi Catalan ${ }^{7}$, and Joan O. Grimalt ${ }^{1}$ \\ ${ }^{1}$ Institute of Environmental Assessment and Water Research (IDÆA-CSIC), Jordi Girona 18, \\ 08034 Barcelona, Catalonia, Spain \\ ${ }^{2}$ Environmental Change Research Centre, University College London, Gower Street, \\ London, WC1E 6BT, UK \\ ${ }^{3}$ Department of Atmospheric and Cryospheric Sciences, University of Innsbruck, \\ Innrain 52, 6020 Innsbruck, Austria \\ ${ }^{4}$ Institute of Interdisciplinary Mountain Research, Austrian Academy of Sciences, \\ Technikerstrasse 21a, 6020 Innsbruck, Austria \\ ${ }^{5}$ Biology Centre, Czech Academy of Science, Institute of Hydrobiology, Na Sadkach 7 , \\ 37005 Ceske Budejovice, Czech Republic \\ ${ }^{6}$ Centre for Advanced Studies of Blanes (CEAB-CSIC), Accés a la Cala St. Francesc 14, \\ 17300 Blanes, Catalonia, Spain \\ ${ }^{7}$ Centre for Ecological Research and Forestry Applications (CREAF), Campus UAB, Edifici C, \\ 08193 Cerdanyola, Catalonia, Spain
}

Correspondence: Pilar Fernández (pilar.fernandez@cid.csic.es)

Received: 21 June 2018 - Discussion started: 24 July 2018

Revised: 21 September 2018 - Accepted: 15 October 2018 - Published: 8 November 2018

\begin{abstract}
Polycyclic aromatic hydrocarbons (PAHs) were analysed in bulk atmospheric deposition samples collected at four European high-mountain areas, Gossenköllesee (Tyrolean Alps), Redon (Central Pyrenees), Skalnate Pleso (High Tatra Mountains), and Lochnagar (Grampian Mountains) between 2004 and 2006. Sample collection was performed monthly in the first three sites and biweekly in Lochnagar. The number of sites, period of study and sampling frequency provide the most comprehensive description of PAH fallout in high mountain areas addressed so far.

The average PAH deposition fluxes in Gossenköllesee, Redon and Lochnagar ranged between 0.8 and $2.1 \mu \mathrm{g} \mathrm{m}^{-2}$ month $^{-1}$, and in Skalnate Pleso it was $9.7 \mu \mathrm{g} \mathrm{m}^{-2}$ month $^{-1}$, showing the influence of substantial inputs from regional emission sources. The deposited distributions of PAHs were dominated by parent phenanthrene, fluoranthene and pyrene, representing 32\%-60\% of the total. The proportion of phenanthrene, the most abundant compound, was higher at the sites of lower temperature,
\end{abstract}

Gossenköllesee and Skalnate Pleso, showing higher transfer from gas phase to particles of the more volatile PAHs. The sites with lower insolation, e.g. those located at lower altitude, were those with a higher proportion of photooxidable compounds such as benz[a]anthracene.

According to the data analysed, precipitation is the main driver of PAH fallout. However, when rain and snow deposition were low, particle settling also constituted an efficient driver for PAH deposition. Redon and Lochnagar were the two sites receiving the highest amounts of rain and snow and the fallout of PAH fluxes was related to this precipitation. No significant association was observed between long-range backward air trajectories and PAH deposition in Lochnagar, but in Redon PAH fallout at higher precipitation was essentially related to air masses originating from the North Atlantic, which were dominant between November and May (cold season). In these cases, particle-normalised PAH fallout was also associated with higher precipitation as these air masses were concurrent with lower temperatures, which en- 
hanced gas to particle partitioning transfer. In the warm season (June-October), most of the air masses arriving at Redon originated from the south and particle deposition was enhanced as consequence of Saharan inputs. In these cases, particle settling was also a driver of PAH deposition despite the low overall PAH content of the Saharan particles.

In Gossenköllesee, the site receiving lowest precipitation, $\mathrm{PAH}$ fallout was also related to particle deposition. The particle-normalised PAH fluxes were significantly negatively correlated to temperature, e.g. for air masses originating from central and eastern Europe, showing a dominant transfer from gas phase to particles at lower temperatures, which enhanced PAH fallout, mainly of the most volatile hydrocarbons.

Comparison of PAH atmospheric deposition and lacustrine sedimentary fluxes showed much higher values in the latter case of $24-100 \mu \mathrm{g} \mathrm{m}^{-2} \mathrm{yr}^{-1}$ vs. $120-3000 \mu \mathrm{g} \mathrm{m}^{-2} \mathrm{yr}^{-1}$. A strong significant correlation was observed between these two fluxes, which is consistent with a dominant origin related to atmospheric deposition at each site.

\section{Introduction}

Polycyclic aromatic hydrocarbons (PAHs) are semi-volatile organic compounds (SOCs) originating from incomplete combustion and pyrolysis of carbonaceous materials. In addition to natural sources, the global emissions of these compounds are dominated by anthropogenic activity such as fossil fuel combustion (Wild and Jones, 1995; Pacyna et al., 2003), which are responsible for their ubiquitous occurrence in the environment, especially in urban/industrial regions. In Europe, the emission of PAHs in 2004 was estimated about $5.1 \times 10^{4}$ tons (calculated for $16 \mathrm{PAHs}$ ), with residential combustion representing $88 \%$ of the total contribution, followed by industrial activities (van der Gong et al., 2007).

The widespread distribution of PAHs is of great environmental concern, since several parent (non-methylated) compounds of this group of hydrocarbons are human carcinogens and priority pollutants (Baek et al., 1991; IARC, 1983; Armstrong et al., 2004). Moreover, the Convention on Longrange Transboundary Air Pollution included PAHs in the list of persistent organic pollutants (POPs) (UNECE, 1998), the emissions of which should be reduced to 1990 levels (EC, 2001). Implementation of regulatory activity caused an initial decrease in PAH emissions (Meijer et al., 2008) but recent studies showed that PAHs have increased globally as a consequence of a higher urban population, energy consumption and vehicle use (van Metre and Mahler, 2005).

Once in the atmosphere, PAHs may remain in the gas phase or associate with particles (Gustafson and Dickhut, 1997; Park et al., 2001; Simcik et al., 1998), be degraded by direct and/or indirect photolysis (Wang et al., 2011a, Zhang et al., 2018) and be deposited by wet and dry processes
(Golomb et al., 2001; Halsall et al., 2001; Feng et al., 2017). Deposited PAHs may revolatilise, be transported over long distances and be deposited again on soil and water surfaces far from the emission sources (Fernández et al., 2003; Singh et al., 2017), e.g. in high-altitude areas (Fernández et al., 2000, 2002; Vilanova et al., 2001; Vives et al., 2004; Grimalt et al., 2001, 2004; Halsall et al., 2001; Arellano et al., 2011; van Drooge et al., 2010; Yang et al., 2016).

Atmospheric deposition is one of the main mechanism of transport of PAHs to all ecosystems (Leister and Baker, 1994). Direct measurements of the atmospheric deposition of these pollutants have mostly been performed in industrial/urban areas (Halsall et al., 1997; Franz et al., 1998; Golomb et al., 2001; Park et al., 2001; Garban et al., 2002; Gigliotti et al., 2005; Gocht et al., 2007; Esen et al., 2008; Wang et al., 2011b; Bari et al., 2014). Only in a few cases has deposition been considered in remote areas such as highaltitude regions (Fernández et al., 2003; Offenthaler et al., 2009; Foan et al., 2012). However, high mountain areas provide the reference background information of the pollution impact, in this case PAHs, of the overall anthropogenic activities in large regions. The study of the processes of transport and pollutant incorporation into these remote ecosystems shows the basic mechanisms of action of these compounds to be far from direct human influence. Understanding of these processes provides basic knowledge for description of the air-to-soil transfer mechanisms in all ecosystems. Furthermore, these remote areas may also act as secondary sources of toxic substances as a consequence of re-emission from terrestrial and aquatic ecosystems by air-water or airsoil exchange or ice/glacier melting (Ma and Cao, 2010; Ma et al., 2011; Kirchgeorg et al., 2016).

To improve the knowledge on how PAHs move through the atmosphere and partition between air and the terrestrial and aquatic environments, bulk atmospheric deposition was collected at four high-altitude sites over 2 years, covering different European climatic and source regions: Redon (2235 m above sea level, Pyrenees), Gossenköllesee (2413 m, Alps), Skalnate Pleso (1787 m, Tatras) and Lochnagar (790 m, Grampian Mountains). Bulk atmospheric deposition (dry and wet) was collected monthly in the three former sites and biweekly in Lochnagar. The samples were analysed to determine seasonal, spatial and temporal trends of atmospheric PAH inputs and to identify the main processes determining PAH fallout at each site. Backward air mass trajectories were calculated using the Hybrid Single-Particle Lagrangian Integrated Trajectory (HYSPLIT) model for assessment of the air sources during sampling. To the best of our knowledge, the number of sites and sampling frequency and period of study constitute the most comprehensive approach performed so far on PAH deposition in high mountain areas. 


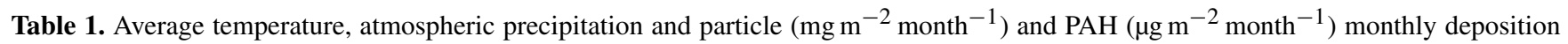
fluxes in the European mountain areas considered in the present study.

\begin{tabular}{|c|c|c|c|c|}
\hline & Lochnagar & Redon & Gossenköllesee & Skalnate Pleso \\
\hline Sampling period & Jun 2004-Mar 2007 & May 2004-Sep 2006 & Jun 2004-Aug 2006 & May 2004-May 2006 \\
\hline Mountain range & Grampian Mountains & Pyrenees & Tyrolean Alps & Tatra Mountains \\
\hline Latitude $(\mathrm{N})$ & 56.95914 & 42.64208 & 47.22528 & 49.189933 \\
\hline Longitude (E) & -3.23128 & 0.77951 & 11.01390 & 20.234217 \\
\hline Altitude (m a.s.1. $)^{\mathrm{a}}$ & 790 & 2235 & 2413 & 1787 \\
\hline Temperature $\left({ }^{\circ} \mathrm{C}\right)^{\mathrm{b}}$ & 4.9 & 5.3 & -1.4 & 2.2 \\
\hline Mean precipitation $\left(\mathrm{mm}\right.$ month $\left.{ }^{-1}\right)$ & 129 & 79 & 66 & 120 \\
\hline Particle flux(min-max $)$ & $130(15-1600)$ & $320(14-2800)$ & $145(18-590)$ & $330(43-1800)$ \\
\hline$\sum \mathrm{PAH}^{\mathrm{c}}(\min -\max )$ & $2.1(0.53-10)$ & $0.80(0.24-1.4)$ & $1.3(0.19-3.7)$ & $9.7(2.3-32)$ \\
\hline Warm & $1.8(0.53-4.4)$ & $0.89(0.24-1.4)$ & $1.3(0.22-3.7)$ & $8.4(2.3-15)$ \\
\hline Cold & $2.25(0.74-10)$ & $0.63(0.24-1.2)$ & $1.3(0.19-3.7)$ & $8.8(3.6-32)$ \\
\hline LMW-PAH ${ }^{\mathrm{d}}(\min -\max )$ & $1.1(0.25-7.6)$ & $0.30(0.06-0.74)$ & $0.89(0.09-3.1)$ & $5.6(1.4-22)$ \\
\hline Warm & $0.94(0.25-2.2)$ & $0.30(0.07-0.74)$ & $0.86(0.10-3.1)$ & $5.7(1.4-10)$ \\
\hline Cold & $1.2(0.39-7.6)$ & $0.28(0.06-0.66)$ & $0.90(0.09-2.8)$ & $4.2(1.7-22)$ \\
\hline HMW-PAH ${ }^{\mathrm{e}}(\min -\max )$ & $0.97(0.08-2.6)$ & $0.49(0.18-0.94)$ & $0.40(0.10-0.84)$ & $3.9(0.73-11)$ \\
\hline Warm & $0.82(0.20-2.6)$ & $0.57(0.21-0.94)$ & $0.42(0.11-0.98)$ & $2.3(0.73-4.1)$ \\
\hline Cold & $1.1(0.08-2.5)$ & $0.34(0.18-0.55)$ & $0.41(0.10-0.84)$ & $4.5(1.6-11)$ \\
\hline PAH $\left(\sum 15 \text { PAH-EPA }\right)^{\mathrm{f}}(\min -\max )$ & $1.9(0.48-9.6)$ & $0.70(0.22-1.3)$ & $1.2(0.17-3.5)$ & $8.8(2.2-29)$ \\
\hline
\end{tabular}

${ }^{a}$ Metres above sea level. ${ }^{b}$ Mean temperature for the whole sampling period. ${ }^{c}$ Sum of all PAHs analysed from acenaphthylene to coronene. ${ }^{d}$ Sum from fluorene to pyrene.

e Sum from benz[a]anthracene to coronene. ${ }^{\mathrm{f}}$ Sum of PAHs included in the EPA list (excluding naphthalene).

\section{Materials and methods}

\subsection{Sampling}

Bulk atmospheric deposition samples were regularly collected at four high mountain European areas (Table 1) over the same period: monthly between 2004 and 2006 in Gossenköllesee (Tyrolean Alps), Redon (Central Pyrenees) and Skalnate Pleso (Tatra Mountains) and biweekly between 2004 and 2007 in Lochnagar (Grampian Mountains) (Fig. 1). All lakes are located in remote areas under special protection. Lake Redon is situated within the Aigüestortes area belonging to the Natura 2000 European network. Lochnagar is located within the Deeside and Lochnagar National Scenic Area, which define protected landscapes in Scotland in the same category as national parks. Gossenköllesee and its catchment area constituted one of the UNESCO Biosphere Reserve from 1977 to 2014, while Skalnate Pleso is situated in the area of the Tatra National Park. Meteorological parameters, i.e. air temperature and precipitation, were provided by automatic weather stations (AWSs) located at each site except in Skalnate Pleso where data were provided by the meteorological observatory of the Earth Science Institute of the Slovak Academy of Science. In summer, precipitation was collected with a polyethylene funnel (different diameter depending on the sampling site) and connected to stainless steel or Teflon-coated reservoirs by a tube. In winter, precipitation occurs as snow and sampling was performed either with a wider tube assembled to the top of a tank or with cylindrical collectors. These devices were equipped with windscreens around the collector's mouth to prevent wind disturbance. The samplers were placed $1.5 \mathrm{~m}$ above ground level. Samples were filtered on site using pre-weighed Whatman glass fibre filters (GF/B, $45 \mathrm{~mm}$ diameter, $1 \mu \mathrm{m}$ pore size) at each field station and the filtrates were solid-phase-extracted with C18 Empore disks ( $47 \mathrm{~mm}$ diameter, $0.5 \mathrm{~mm}$ thickness) as described elsewhere (Carrera et al., 1998). After sample removal, the bulk collectors were rinsed with Milli-Q water, which was filtered and solid-phase-extracted with the same disk used for the corresponding deposition sample. Glass fibre filters and disks were wrapped in aluminium foil and transported frozen to the laboratory. More details on sampling procedures are reported elsewhere (Arellano et al., 2015).

\subsection{Extraction and clean-up}

Glass-fibre filters were freeze-dried and weighed for measuring total particle content in bulk atmospheric deposition. PAHs were extracted from the filters by sonication with dichloromethane:methanol $(2: 1)(3 \times 10 \mathrm{~mL}$, 20 min each). The pollutants adsorbed in the $\mathrm{C}_{18}$ disks were eluted sequentially with methanol, cyclohexane and dichloromethane (Carrera et al., 1998). Both phases were combined and purified by column adsorption chromatography with aluminium oxide after adding a recovery standard mixture of perdeuterated anthracene- $d_{10}$, benz[a]anthracene$d_{10}$, benzo[b]fluoranthene- $d_{12}$ and benzo[ghi]perylene- $d_{12}$ (Dr. Ehrenstorfer GmbH; Augsburg, Germany). Prior to instrumental analysis, samples were spiked with an internal 


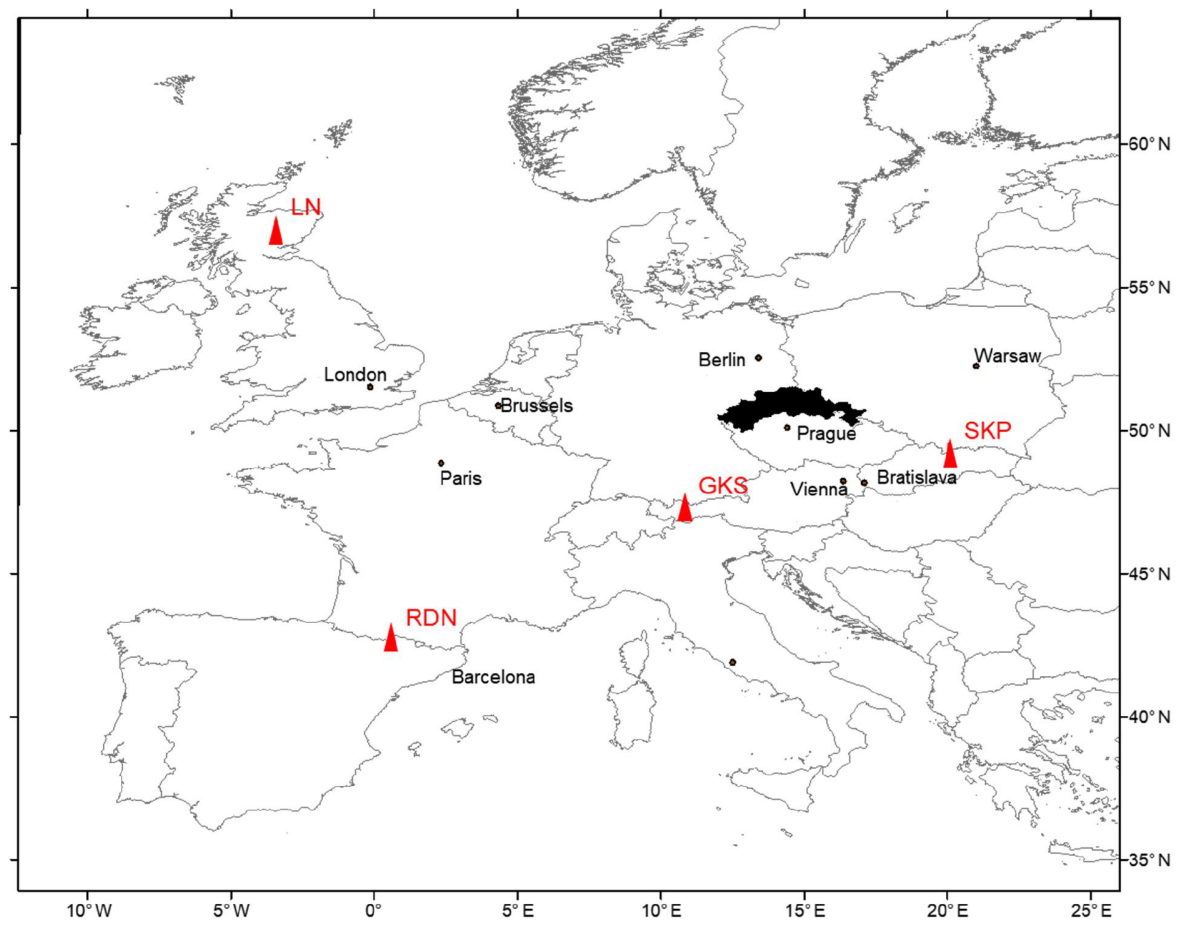

Figure 1. Location of the high-altitude areas included in this study. Lake identification: LN is Lochnagar, RDN is Lake Redon, GKS is Gossenköllesee and SKP is Skalnate Pleso. Situation of the Black Triangle between Germany, Poland and Czech Republic is indicated by a shaded area.

standard mixture of pyrene- $d_{10}$ and perylene- $d_{12}$ dissolved in isooctane.

\subsection{Instrumental analysis}

PAHs were analysed by gas chromatography-mass spectrometry (GC-MS; Trace DSQ II Instrument Thermo, Austin, USA.) using a $60 \mathrm{~m}$ HP-5MS column $(0.25 \mathrm{~mm}$ i.d. $\times 0.25 \mu \mathrm{m}$ film thickness). The oven temperature programme started at $90^{\circ} \mathrm{C}$ (held for $1 \mathrm{~min}$ ) and increased to $120^{\circ} \mathrm{C}$ at $10^{\circ} \mathrm{C} \mathrm{min}{ }^{-1}$, and then to $310^{\circ} \mathrm{C}$ at $6^{\circ} \mathrm{C} \mathrm{min}^{-1}$ (final holding time $25 \mathrm{~min}$ ). Injector, transfer line and ion source temperatures were 280,270 and $250^{\circ} \mathrm{C}$. Helium was used as the carrier gas $\left(1.2 \mathrm{~mL} \mathrm{~min}^{-1}\right)$. The injector operated in splitless mode. Data were acquired in electron impact and selective ion monitoring modes. Further details on the ions selected for quantification and mass spectrometric conditions are reported elsewhere (Fernández et al., 1999).

\subsection{Quality control and assurance}

Quantification was performed by the internal standard method. Recoveries of the analytical procedure were evaluated using surrogate standards. The reported values were corrected by these recoveries, which varied between $76 \%$ for benz[a]anthracene- $d_{10}$ and $53 \%$ for benzo[ghi]perylene- $d_{12}$.
Field and procedural blanks were collected at each sampling site and processed together with the samples. For field blanks, Milli-Q water was filtered and solid-phase adsorbed, transported and stored for subsequent analysis. In general, blank values represented less than $10 \%$ of bulk deposition sample concentrations. These values were used to determine method detection limits (MDLs) that were established as average blank values plus 3 times the standard deviation. These limits ranged between 0.45 and 28 pg depending on the compound.

\subsection{Back trajectory air mass calculations}

Three-day back trajectories were calculated using the Hybrid Single-Particle Lagrangian Integrated Trajectory (HYSPLIT data available at http://ready.arl.noaa.gov/HYSPLIT. php) modelling system developed by the National Oceanic and Atmospheric Administration (NOAA) Air Resources Laboratory (ARL) (Draxler and Hess, 1998; Draxler and Rolph, 2013).

The meteorological data used to compute the 6-hourly back trajectories were obtained from the National Centre for Environmental Prediction (NECP) Global Data Assimilation System (GDAS) and from Eta Data Assimilation System (EDAS). The trajectories were calculated for those days with precipitation (rain or snow) and every 2 days when no precipitation was recorded by the AWS. 
Table 2. Comparison of PAH deposition fluxes with those reported in the literature.

\begin{tabular}{|c|c|c|c|c|c|}
\hline Sampling site & Sampling period & Site type & $\begin{array}{r}\sum 15 \text { PAH-EPA } \\
\left(\mu \mathrm{g} \mathrm{m}^{-2} \mathrm{~d}^{-1}\right)\end{array}$ & $\begin{array}{r}\text { Benzo[a]pyrene } \\
\text { (ng m }{ }^{-2} \text { month }^{-1} \text { ) }\end{array}$ & Reference \\
\hline Skalnate Pleso & May 2004-May 2006 & remote & 0.28 & 280 & This study \\
\hline Lochnagar & Jun 2004-Mar 2007 & remote & 0.06 & 61 & This study \\
\hline Gossenköllesee & Jun 2004-Aug 2006 & remote & 0.04 & 20 & This study \\
\hline Redon & May 2004-Sep 2006 & remote & 0.02 & 51 & This study \\
\hline Gossenköllesee & Oct $1996-O c t 1998$ & remote & 0.038 & 22 & Fernandez et al. (2003) \\
\hline Redon & Mar 1997-Oct 1998 & remote & 0.052 & 59 & Fernandez et al. (2003) \\
\hline$\varnothing_{\text {vre Neadalsvatn }}$ & Dec 1997, Apr-Aug 1998 & remote & 0.063 & 41 & Fernandez et al. (2003) \\
\hline Chesapeake Bay & Jun 1990-Dec 1991 & remote & 0.55 & 500 & Leister and Baker (1994) \\
\hline Chesapeake Bay & 1991 & remote & $0.4-0.55$ & 500 & Dickhut and Gustafson (1995) \\
\hline Siskiwit Lake (Lake Superior, USA) & $1983-1984$ & remote & 0.46 & 225 & McVeety and Hites (1988) \\
\hline Natural Park (northern Spain) & Jun 2010-May 2011 & remote & 0.18 & & Foan et al. (2012) \\
\hline Southern Ontario (Canada) & Oct 2001-Dec 2002 & remote & 0.41 & 345 & Su et al. (2007) \\
\hline Southern Italy & Dec 2003-Jan 2004 & rural & $0.09(0.07-0.15)$ & 140 & Menichini et al. (2006) \\
\hline Southern Germany & Aug 2001-Aug 2002 & rural & 0.55 & & Gocht et al. (2007) \\
\hline Beijing-Tianjin region & Jun 2007-May 2008 & rural & 3.9 & & Wang et al. (2011b) \\
\hline Pleumeur-Bodou (France) & Oct $1999-$ Oct 2000 & rural & 0.14 & 15000 & Garban et al. (2002) \\
\hline Balaton Lake (Hungary) & 1996-1997 & rural & $0.51-0.81$ & $1000-1500$ & Kiss et al. (2001) \\
\hline Abeschviller (France) & Oct $1999-O c t 2000$ & forest & 0.19 & 15000 & Garban et al. (2002) \\
\hline Bayreuth (Germany) & May 1995-Apr 1996 & forest & $0.42-2.4$ & $620-1700$ & Horstmann and Mclachlan (1998) \\
\hline Gardsjon (Sweden) & $1991-1994$ & forest & 0.51 & & Brorstrom-Lunden et al. (1998) \\
\hline Western Mediterranean Sea & 1989-1990 & coastal & 0.13 & 183 & Lipiatou et al. (1997) \\
\hline Eastern Mediterranean & Nov 2000-Jul 2002 & coastal & 0.46 & & Tsapakis et al. (2006) \\
\hline Atlantic Ocean (Canada) & $1998-2000$ & coastal & 0.12 & $25-75$ & Brun et al. (2004) \\
\hline New England coast & Dec 1998-May 2000 & coastal & 0.22 & & Golomb et al. (2001) \\
\hline Galvesston Bay (Texas, USA) & Feb 1995-Aug 1996 & coastal & 0.63 & & Park et al. (2001) \\
\hline New Jersey & Jun 1999-Aug 2002 & coastal & 1.0 & 1.6 & Gigliotti et al. (2005) \\
\hline New Jersey & Feb 1998-Jan 2003 & coastal & $0.4-6.1$ & $1.3-24$ & Gigliotti et al. (2005) \\
\hline Tampa Bay & May-Aug 2002 & coastal & 6.8 & 120 & Poor et al. (2004) \\
\hline Beijing-Tianjin region & Jun 2007-May 2008 & background & 0.82 & & Wang et al. (2011b) \\
\hline Western Greece & Jan 2001-Oct 2002 & background & 0.19 & & Terzi and Samara (2005) \\
\hline New Jersey & Feb 1998-Aug 2002 & suburban & $0.81-3.1$ & $1.7-12$ & Gigliotti et al. (2005) \\
\hline Evreux (France) & Mar 2001-Feb 2002 & suburban & 0.13 & & Motelay-Massei et al. (2003) \\
\hline Yangsuri, Yangpyoung & Feb-May 2000 & suburban & $5.5-24$ & & Bae et al. (2002) \\
\hline Taichung (Taiwan) & Aug-Dec 2002 & suburban & 39 & & Fang et al. (2004) \\
\hline Izmit Bay (Turkey) & Sep 2002-Jul 2003 & urban & 8.3 & 1500 & Pekey et al. (2007) \\
\hline Manchester & 1991-1992 & urban & 5.2 & 9000 & Halsall et al. (1997) \\
\hline Cardiff & 1991-1992 & urban & 4.1 & 6600 & Halsall et al. (1997) \\
\hline Taichung (Taiwan) & Aug-Dec 2002 & urban & 49 & & Fang et al. (2004) \\
\hline Beijing-Tianjin region & Jun 2007-May 2008 & urban & 8.3 & & Wang et al. (2011b) \\
\hline Paris & Oct $1999-$ Oct 2000 & urban & 0.63 & & Garban et al. (2002) \\
\hline Paris (France) & Nov 1999-Oct 2000 & urban & $0.64(0.2-2.0)$ & & Ollivon et al. (2002) \\
\hline Seoul and Inchon & Feb-May 2000 & urban & $5.5-24$ & & Bae et al. (2002) \\
\hline New Jersey & Feb 1998-Aug 2002 & urban & $11-16$ & $42-54$ & Gigliotti et al. (2005) \\
\hline Bursa (Turkey) & Jul 2004-Mar 2005 & industrial & $0.3-19.5$ & & Esen et al. (2008) \\
\hline
\end{tabular}

Different altitudes were used to calculate the trajectories. Usually, they did not show differences; thus altitudes representing the air mass above the sampling point were selected at $3000 \mathrm{~m}$ above sea level (a.s.1.) in Redon and Skalnate Pleso, $3500 \mathrm{~m}$ a.s.1. for Gossenköllesee and $2000 \mathrm{~m}$ a.s.1. for Lochnagar. The total number of backward trajectories was 1968, being 335, 475, 598 and 560 for Redon, Gossenköllesee, Lochnagar and Skalnate Pleso. More details on air mass trajectory determination can be found in Arellano et al. (2014).

\section{Results and discussion}

\subsection{Atmospheric PAH deposition fluxes. Spatial and temporal variability}

Mean, minimum and maximum atmospheric deposition fluxes of the PAHs at the four sampling sites during the studied period are summarised in Table 1. A strong contrast is found between the total PAH mean fluxes found in Lochnagar, Gossenköllesse and Redon of 0.80-2.1 $\mathrm{g} \mathrm{m} \mathrm{m}^{-2}$ month $^{-1}$, and in Skalnate Pleso of $9.7 \mu \mathrm{g} \mathrm{m}^{-2}$ month $^{-1}$, the latter showing PAH deposition fluxes between 5 and 10 times higher than the others. In Table 2, these deposition fluxes are compared with those observed in different environments, 
e.g. remote, rural, coastal, industrial, suburban and urban areas. In addition, the deposition fluxes of benzo[a]pyrene are also included in this Table for comparison. This hydrocarbon is a known carcinogen taken for reference in regulatory pollution values of PAH concentrations. As observed for total PAHs, the benzo[a]pyrene mean deposition fluxes in Skalnate Pleso, $280 \mathrm{ng} \mathrm{m}^{-2}$ month $^{-1}$, are much higher than those observed in Lochnagar, Gossenköllesee and Redon, 20-61 ng m ${ }^{-2}$ month $^{-1}$ (Table 2).

The observed PAH deposition fluxes in these high mountain European areas, $0.02-0.28 \mu \mathrm{g} \mathrm{m}^{-2} \mathrm{~d}^{-1}$, range among the lowest values reported in the literature (Table 2). Thus, PAH deposition fluxes of $0.40-0.55 \mu \mathrm{g} \mathrm{m}^{-2} \mathrm{~d}^{-1}$ have been recorded at remote sites from the USA (Su et al., 2007; McVeety and Hites, 1988; Leister and Baker, 1994; Dickhut and Gustafsson, 1995), whereas Foan et al. (2012) reported mean deposition fluxes of PAHs of $0.18 \mu \mathrm{g} \mathrm{m}^{-2} \mathrm{~d}^{-1}$ in remote areas of northern Spain. The reported PAH depositions in background areas are again higher than those observed in the high mountain European sites, $0.19-0.82 \mu \mathrm{g} \mathrm{m}^{-2} \mathrm{~d}^{-1}$ (Brorstrom-Lunden et al., 1998; Horstmann and McLachlan, 1998; Garban et al., 2002). Higher PAH deposition has also been measured in rural areas, $0.09-3.9 \mu \mathrm{g} \mathrm{m}^{-2} \mathrm{~d}^{-1}$ (Kiss et al., 2001; Garban et al., 2002; Menichini et al., 2006; Gocht et al., 2007; Wang et al., 2011b) or in coastal sites, 0.4-6.8 $\mu \mathrm{g} \mathrm{m}^{-2} \mathrm{~d}^{-1}$ (Lipiatou et al., 1997; Golomb et al., 2001; Park et al., 2001; Brun et al., 2004; Poor et al., 2004; Gigliotti et al., 2005; Tsapakis et al., 2006). As expected, the PAH deposition fluxes measured in industrial areas, 0.3$19.5 \mu \mathrm{g} \mathrm{m}^{-2} \mathrm{~d}^{-1}$ (Esen et al., 2008), in suburban areas, 0.13$39 \mathrm{\mu g} \mathrm{m}^{-2} \mathrm{~d}^{-1}$ (Bae et al., 2002; Motelay-Massei et al., 2003; Fang et al., 2004; Gigliotti et al., 2005), and in urban areas 0.63-49 $\mu \mathrm{g} \mathrm{m}^{-2} \mathrm{~d}^{-1}$ (Halsall et al., 1997; Bae et al., 2002; Garban et al., 2002; Ollivon et al., 2002; Fang et al., 2004; Gigliotti et al., 2005; Pekey et al., 2007; Wang et al., 2011b), are higher than those in the remote European mountains.

Concerning the benzo[a]pyrene deposition fluxes, again those observed in the European high mountains, 20$280 \mathrm{ng} \mathrm{m}^{-2}$ month $^{-1}$, range among the lowest described (Table 2). However, the values reported for different types of sites do not show uniform trends such as those observed when considering total PAH deposition. Thus, benzo[a]pyrene deposition fluxes ranged between 225 and $500 \mathrm{ng} \mathrm{m}^{-2}$ month $^{-1}$ in remote sites (Su et al., 2007; McVeety and Hites, 1988; Leister and Baker, 1994; Foan et al., 2012). In forested and rural areas, the benzo[a]pyrene deposition has been measured to account between 140 and $15000 \mathrm{ng} \mathrm{m}^{-2}$ month $^{-1}$ (Horstmann and McLachan, 1998; Garban et al., 2002; Kiss et al., 2001; Menichini et al., 2006). Finally, benzo[a]pyrene fluxes between 42 and $9000 \mathrm{ng} \mathrm{m}^{-2}$ month $^{-1}$ have been reported in urban sites (Halsall et al., 1997; Gigliotti et al., 2005; Pekey et al., 2007).

The differences between Lochnagar, Gossenköllesee, and Redon, and separately at Skalnate Pleso cannot be explained by differences in precipitation (e.g. $120 \mathrm{~mm} \mathrm{month}^{-1}$ in
Skalnate Pleso and $66-129 \mathrm{~mm} \mathrm{month}^{-1}$ in the other sites) (Table 1) or particle flux $\left(330 \mathrm{mg} \mathrm{m}^{-2} \mathrm{month}^{-1}\right.$ in Skalnate Pleso and $145-320 \mathrm{mg} \mathrm{m}^{-2}$ month $^{-1}$ in the other lakes) (Table 1). The higher PAH deposition in Skalnate Pleso compared to the other sites is in agreement with atmospheric PAH concentrations and probably reflects regional contributions from industrial emissions by factories located in southern Poland and other areas such as the Black Triangle (Fig. 1) (van Drooge et al., 2010). This geographical difference is consistent with PAH concentrations reported in air on a European scale, which identified high PAH emissions in eastern Europe (Jaward et al., 2004).

Comparison of the PAH deposition measured in Gossenköllesee and Redon in 2004-2006 with those found in 1996-1998 (Fernandez et al., 2003) shows nearly the same values at Gossenköllesee (Table 2) but statistically significant differences in Redon $(p>0.05)$, involving lower fluxes in the 2004-2006 period. In both cases, the deposition fluxes range among the lowest measured in remote sites (Table 2), which suggest that they correspond to background concentrations of long-range-transported PAHs and not to direct pollution inputs. A very similar deposition of total particles has been measured in Gossenköllesee in the two sampling periods, $145 \mathrm{mg} \mathrm{m}^{-2}$ month $^{-1}$ in 4 June-6 August (Table 1) and $130 \mathrm{mg} \mathrm{m}^{-2} \mathrm{month}^{-1}$ in October 1996-October 1998 (Fernandez et al., 2003), whereas total precipitation shows a strong difference, with lower values in 2004-2006 of $66 \mathrm{~mm} \mathrm{month}^{-1}$ (Table 1) vs. $110 \mathrm{~mm} \mathrm{month}^{-1}$ (Fernandez et al., 2003) in the 1996-1998 period. Precipitation in the recent period is quite low, suggesting that the PAH fallout fluxes at Gossenköllesee were mainly determined by particle deposition. By contrast, in Redon both decreases in particle deposition of $320 \mathrm{mg} \mathrm{m}^{-2}$ month $^{-1}$ (Table 1) from $420 \mathrm{mg} \mathrm{m}^{-2}$ month $^{-1}$ (Fernandez et al., 2003) and atmospheric precipitation of $79 \mathrm{~mm} \mathrm{month}^{-1}$ (Table 1) from $110 \mathrm{~mm} \mathrm{month}^{-1}$ (Fernandez et al., 2003) are observed when comparing the recent (4 May-6 September) and previous sampling periods (March 1997-October 1998). The differences in the deposition of particles and wet precipitation are consistent with the lower PAH fallout from the atmosphere observed at this site in 2004-2006.

\subsection{PAH composition}

Overall, the PAH composition in the atmospheric deposition samples was dominated by parent compounds and, among these, the low molecular weight fraction (LMWPAHs, from acenaphthene to pyrene). Phenanthrene, fluoranthene and pyrene were the most abundant, representing between $32 \%$ and $60 \%$ of the total PAH mixture (Fig. 2). These compounds are also the most abundant in the atmosphere, namely in the gas phase (Fernández et al., 2002). Dominance of LMW-PAHs in atmospheric deposition and, particularly, phenanthrene, fluoranthene and pyrene, is a common feature of studies in Europe (Halsall et al., 1997; Holoubek et al., 


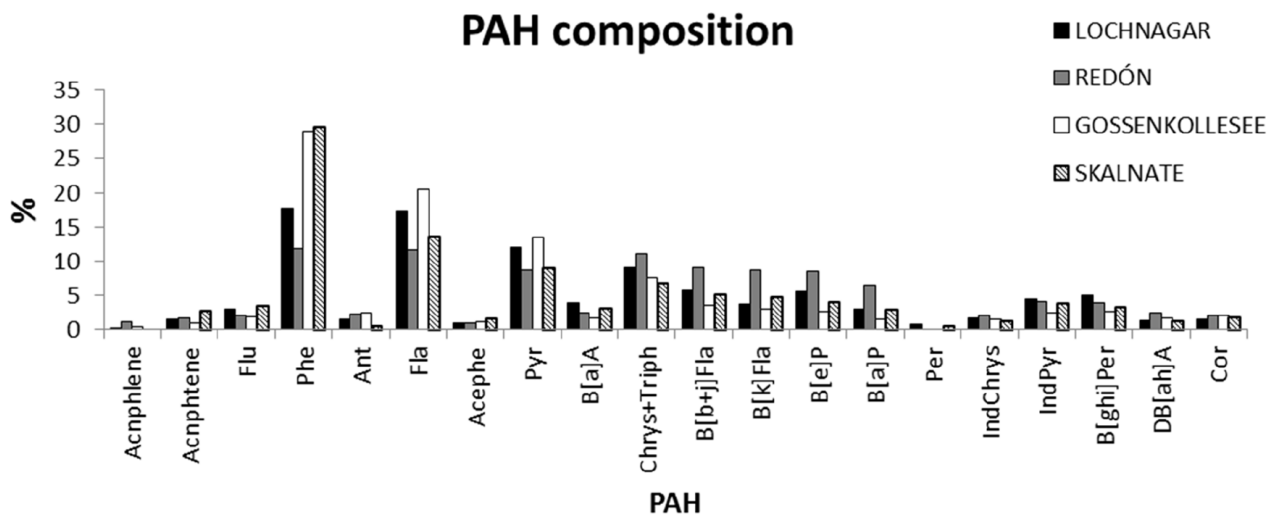

Figure 2. Qualitative distribution of PAH mixtures in atmospheric deposition samples. Compound identification: Acnphlene is acenaphthylene, Acnphtene is acenaphthene, Flu is fluorene, Phe is phenanthrene, Ant is anthracene, Fla is fluoranthene, Acephe is acephenanthrilene, Pyr is pyrene, B[a]A is benz[a]anthracene, Chrys + Triph is chrysene + triphenilene, $\mathrm{B}[\mathrm{b}+\mathrm{j}] \mathrm{Fla}$ is benzo[b]fluoranthene + benzo[j]fluoranthene, $\mathrm{B}[\mathrm{k}] \mathrm{Fla}$, benzo[k]fluoranthene, $\mathrm{B}[\mathrm{e}] \mathrm{P}$ is benzo[e]pyrene, $\mathrm{B}[\mathrm{a}] \mathrm{P}$ is benzo[a]pyrene, Per is perylene, IndChrys is indeno[7,1,2,3-cdef]chrysene, IndPyr is indeno[1,2,3-cd]pyrene, B[ghi]Per is benzo[ghi]perylene, DB[ah]A is dibenz[a,h]anthracene, Cor is coronene.

Table 3. Average PAH isomeric ratios in atmospheric deposition.

\begin{tabular}{lccc}
\hline & Pyr / Fla + Pyr $)$ & $\mathrm{BaA} /(\mathrm{BaA}+\mathrm{Chrys})$ & $\mathrm{BaP} /(\mathrm{BaP}+\mathrm{BeP})$ \\
\hline Gossenköllesee & & \\
\hline Mean & $0.40 \pm 0.03$ & $0.18 \pm 0.04$ & $0.38 \pm 0.10$ \\
Warm $^{\mathrm{a}}$ & $0.41 \pm 0.04$ & $0.19 \pm 0.04$ & $0.31 \pm 0.13$ \\
Cold $^{\mathrm{a}}$ & $0.39 \pm 0.02$ & $0.17 \pm 0.04$ & $0.39 \pm 0.06$ \\
\hline Redon & & \\
\hline Mean & $0.43 \pm 0.02$ & $0.17 \pm 0.04$ & $0.42 \pm 0.05$ \\
Warm & $0.42 \pm 0.02$ & $0.18 \pm 0.03$ & $0.41 \pm 0.05$ \\
Cold & $0.43 \pm 0.02$ & $0.17 \pm 0.05$ & $0.43 \pm 0.05$ \\
\hline Skalnate Pleso & & & \\
\hline Mean & $0.40 \pm 0.02$ & $0.28 \pm 0.07$ & $0.45 \pm 0.12$ \\
Warm & $0.41 \pm 0.01$ & $0.22 \pm 0.04$ & $0.51 \pm 0.18$ \\
Cold & $0.40 \pm 0.02$ & $0.32 \pm 0.05$ & $0.42 \pm 0.07$ \\
\hline Lochnagar & & & \\
\hline Mean & & & $0.33 \pm 0.12$ \\
Warm & $0.41 \pm 0.06$ & $0.31 \pm 0.06$ & $0.36 \pm 0.10$ \\
Cold & $0.42 \pm 0.08$ & $0.32 \pm 0.06$ & $0.31 \pm 0.11$ \\
\hline
\end{tabular}

a June-October, ${ }^{\text {b }}$ November-May

2007; Fernández et al., 2003; Cetin et al., 2016), America (Gigliotti et al., 2005; Brun et al., 2004) and Asia (Li et al., 2009; Wang et al., 2011b; Sharma et al., 2018).

In the present study, no significant differences in qualitative composition between sites were observed, except for the relative proportion of phenanthrene, the most volatile and abundant compound. The PAH distributions from the sites with lower annual mean temperature, Gossenköllesee and Skalnate Pleso at -1.4 and $2.2{ }^{\circ} \mathrm{C}$ respectively (Table 1), were those with highest proportion of this compound (31\%$32 \%$ ), whereas the lowest was observed in Redon (12\%, $\left.5.3^{\circ} \mathrm{C}\right)$. Lochnagar $\left(4.9^{\circ} \mathrm{C}\right)$ also showed a low but intermediate proportion of phenanthrene (18\%). Higher local temperatures likely involve lower condensation of the most volatile PAHs and therefore lower deposition fluxes.

Consistently with these differences in phenanthrene content, the coldest sites, Gossenköllesee and Skalnate Pleso, were those with the highest deposition of low and high 
molecular weight PAHs, of 0.89 and $0.40 \mu \mathrm{g} \mathrm{m}^{-2}$ month $^{-1}$ and 5.6 and $3.9 \mu \mathrm{g} \mathrm{m}^{-2}$ month $^{-1}$ (Table 1), whereas this proportion was inverse in Redon, with 0.30 and $0.49 \mu \mathrm{g} \mathrm{m}^{-2} \mathrm{month}^{-1}$, and about the same in Lochnagar, with 1.1 and $0.97 \mu \mathrm{g} \mathrm{m}^{-2}$ month $^{-1}$ (Table 1).

Further assessment on the qualitative changes in PAH composition between samples can be obtained from the study of diagnostic ratios (Table 3; Sicre et al., 1987). The pyrene / (fluoranthene + pyrene) ratios showed a uniform composition between samples and therefore no environmental dependence. In contrast, the sites located at lower altitude, e.g. Lochnagar $(790 \mathrm{~m})$ and Skalnate $(1787 \mathrm{~m})$ were those with a higher relative proportion of benz[a]anthracene to its less labile to photooxidation isomer, chrysene (Ding et al., 2007; Xing et al., 2016). The lower-altitude sites receive less insolation than those located at higher altitude. Accordingly, the average benz[a]anthracene / (chrysene + benz[a]anthracene) ratios were higher in Skalnate $(1787 \mathrm{ma.s.1}$.) and Lochnagar (790 ma.s.1.), between 0.28 and 0.31 , than in Gossenköllesee (2413 ma.s.l.) and Redon (2230 m a.s.1.), 0.17-0.18 (Table 3). Furthermore, the average benz[a]anthracene / (chrysene + benz[a]anthracene) ratio in Skalnate Pleso $(0.28 ; 1787 \mathrm{~m})$ was even lower than the one in Lochnagar $(0.31 ; 790 \mathrm{~m})$. Thus, insolation and not local temperature was the main driver of the relative changes between benz[a]anthracene and chrysene in all sites. Differentiation between the cold (November-May) and the warm (June-October) sampling periods, involving higher insolation in the latter, did not show significant differences in this ratio in Gossenköllesee, Redon and Lochnagar (Table 3). However, in Skalnate Pleso higher benz[a]anthracene / (chrysene + benz[a]anthracene) ratio was observed in the cold season (Table 3), which confirmed a predominant insolation effect in the relative concentrations of these two PAHs.

The average benzo[a]pyrene / (benzo[e]pyrene + benzo[a]pyrene) ratios found in Gossenköllesee, Redon and Skalnate Pleso were also consistent with insolation differences, since the proportion of benzo[a]pyrene, the compound more labile to photooxidation, was higher at the lower-altitude sampling sites, at $0.38,0.42$ and 0.45 (Table 3). However, this trend was not observed in Lochnagar, the lowest-altitude site, which showed the lowest average benzo[a]pyrene / (benzo[e]pyrene + benzo[a]pyrene) ratio. In general, the benzo[a]pyrene/(benzo[e]pyrene + benzo[a]pyrene) ratio is less sensitive to photooxidation than the benz[a]anthracene / (chrysene + benz[a]anthracene) ratio (Behymer and Hites, 1988).

\subsection{Meteorological drivers of PAH atmospheric deposition}

The influence of particle deposition, precipitation and temperature on PAH fallout fluxes at these remote sites was in- vestigated. Pearson correlation coefficients between the logtransformed PAH monthly deposition fluxes and these variables were calculated at each site. The statistically significant correlations found at $95 \%(p<0.05)$ and $99 \%(p<0.01)$ confidence levels are shown in Table 4.

In Redon and Lochnagar, the two sites receiving highest precipitation, the fallout fluxes of most of these hydrocarbons were directly correlated to wet deposition, e.g. higher precipitation involving higher PAH fallout. At these two sites, no significant correlations were observed between PAH fluxes and particle deposition or temperature. Normalisation of PAH fallout to particle deposition also showed significant positive correlations with precipitation $(p<0.01)$, which corroborated the dominant role of rain and snow in the transfer of PAHs from the atmosphere to the soil. These results are also consistent with reports indicating that particle scavenging processes are significant mechanisms of PAH removal from the atmosphere (Gocht et al., 2007; Li et al., 2016).

In Gossenköllesee, the site receiving lowest precipitation, $66 \mathrm{~mm}$ month $^{-1}$ (Table 1), PAH fallout was significantly correlated to particle deposition for the higher molecular weight PAHs $(p<0.05$; Table 4$)$ and no correlation was observed between PAH fluxes and precipitation. Normalisation of the PAH fluxes to particle deposition showed significant negative correlations with precipitation for some compounds in the low molecular weight range, e.g. fluoranthene, pyrene and chrysene $(p<0.05$; Table 4$)$. The particle-normalised deposition flows of these compounds were also negatively correlated to temperature. Lower temperatures enhance the PAH transfer from gas phase to particles and this effect is stronger among the PAHs of higher volatility, such as fluoranthene, pyrene and chrysene. This association with the particulate matter increases the deposition of these compounds.

Previous studies considering the gas-particle partitioning of these compounds in Gossenköllesee, Redon and Skalnate Pleso showed that the observed distributions in Gossenköllesee and Skalnate more closely followed the theoretical slope constants of the correlations between gas-phase partition coefficients and octanol-air constants (Fernandez et al., 2002; van Drooge et al., 2010), which was consistent with a temperature-dependent reversible transfer between gas phase and particle adsorption. Moreover, the significant negative correlations of the particle-normalised deposition fluxes of these compounds in Gossenköllesee with precipitation may be explained by the significant positive correlation between precipitation and temperature at this site. Accordingly, in the cold period lower precipitation and higher particle-normalised PAH deposition were observed.

Skalnate Pleso has some specific features since this location receives enhanced PAH inputs from regional emissions. These emissions involve the release of large amounts of particulate matter containing PAHs (van Drooge et al., 2010). This site received the highest particle deposition flux, $330 \mu \mathrm{g} \mathrm{m}^{-2}$ month $^{-1}$ (Table 1), and PAH fallout was significantly correlated with particle deposition $(p<0.05$; 


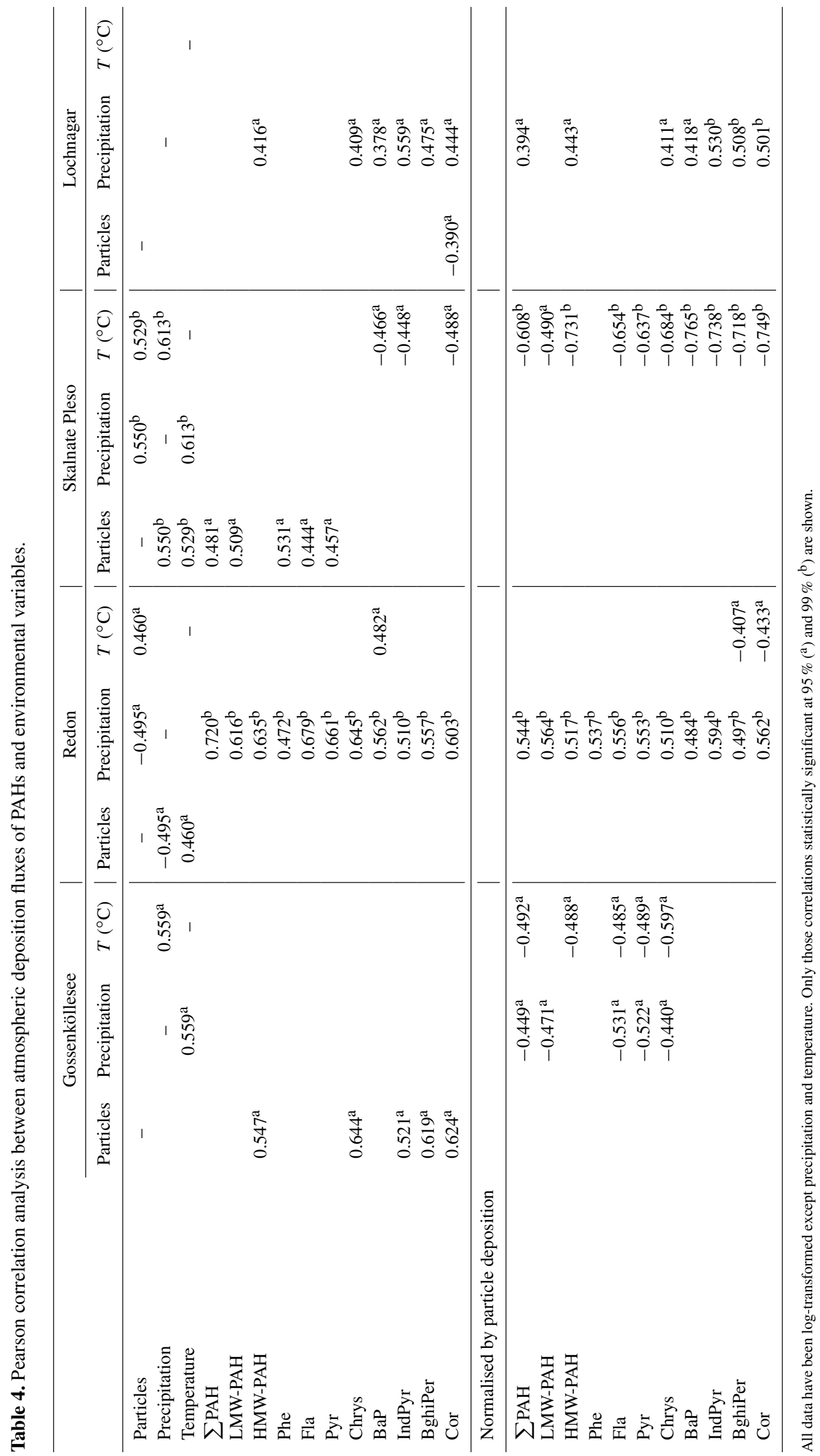




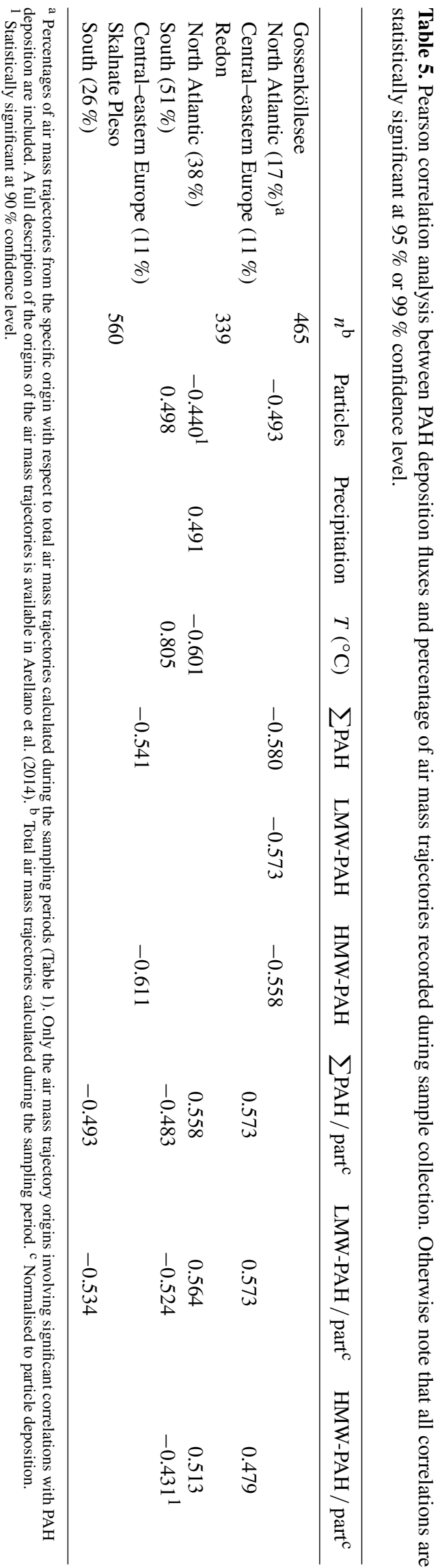

Table 4). Some PAHs, e.g. benzo[a]pyrene $\left(R^{2}=0.585\right)$, benzo[ghi]perylene $\left(R^{2}=0.516\right.$ at $\left.p<0.001\right)$ and coronene $\left(R^{2}=0.561\right)$, also showed significant negative correlations with temperature $(p<0.05$; Table 4$)$, which may reflect the effects of higher winter production of electric power or other combustion processes in the region. These results are consistent with previous studies in urban and rural areas (Schifman and Boving, 2015; Birgul et al., 2011; Gaga et al., 2009; Gocht et al., 2007; Brun et al., 2004; Shahpoury et al., 2015), which also found higher PAH fluxes in winter. The observed seasonal trend in Skalnate Pleso could reflect direct impacts of regional sources, while Redon, Lochnagar and Gossenköllesee received PAH mixtures from more distant areas and no significant seasonal influences were recorded.

Normalisation of the PAH fallout to particle deposition showed that precipitation is not a main driver of the transfer of these hydrocarbons from atmosphere to soil in Skalnate Pleso. However, temperature appeared as a significant parameter that was negatively correlated with PAH deposition fluxes ( $p<0.05$; Table 4$)$. As in the case of Gossenköllesee, these negative correlations may reflect the higher adsorption of PAHs to particles at lower temperatures, involving higher particle PAH content and therefore higher deposition fluxes of these hydrocarbons. Lower temperatures enhance the capacity of settling particles for the transfer of PAHs from atmosphere to soil.

\subsection{Correlation with air mass back trajectories}

Determination of the PAH source regions for each site was performed by $72 \mathrm{~h}$ backward trajectory analyses using the HYSPLIT model for the entire sampling periods (Table 1). A detailed description of the back trajectory analyses performed in each study site is reported elsewhere (Arellano et al., 2014). Air mass back trajectories and their contributions to the total trajectories measured in each sampling period were assigned to each monthly deposition sample. The number of trajectories calculated in each sampling site is indicated in Table 5.

The relationship between air mass trajectories and PAH deposition was investigated for each sample. No trend was observed at Lochnagar, indicating diffuse PAH inputs from unspecific sources in this site.

In Skalnate Pleso, a negative dependence between particlenormalised PAH fluxes and air masses from the south was observed, which may indicate that particles from this origin were depleted in PAH content (Table 5).

In Gossenköllesee, total particle mass was negatively correlated with air masses from the North Atlantic (Table 5). These air masses were also negatively correlated with total PAHs, including LMW-PAHs and HMW-PAHs (from benzo[a]anthracene to coronene) (Table 5), which is consistent with the predominant role of particle deposition at this site (Table 4). Normalisation of PAH fallout to particle de- 
Table 6. Comparison between atmospheric deposition and lacustrine sediment fluxes of PAHs in the study regions $\left(\mu \mathrm{g} \mathrm{m}^{-2} \mathrm{yr}^{-1}\right)$.

\begin{tabular}{|c|c|c|c|c|c|}
\hline & Lochnagar & Redon & Gossenköllesee & \multicolumn{2}{|c|}{ Skalnate Pleso ${ }^{\mathrm{a}}$} \\
\hline Sampling period & Jun 2004-Mar 2007 & May 2004-Sep 2006 & Jun 2004-Aug 2006 & \multicolumn{2}{|c|}{ May 2004-May 2006} \\
\hline \multicolumn{6}{|l|}{ Sediment fluxes } \\
\hline Sampling year & 2001 & 1991 & 1998 & 1991 & 2001 \\
\hline Lake area (ha) & 10.4 & 24 & 1.7 & 0.71 & 1.7 \\
\hline$\sum \mathrm{PAH}$ concentration $\left(\mathrm{ng} \mathrm{g}^{-1} \mathrm{dw}\right)$ & 4000 & 680 & 780 & 18000 & 8700 \\
\hline $\bar{\sum} \mathrm{PAH}$ total fluxes & 480 & 120 & 125 & 3000 & 1400 \\
\hline$\sum$ PAH total fluxes (estimated) ${ }^{\mathrm{b}}$ & 260 & 62 & 780 & 452 & 850 \\
\hline$\sum$ PAH ratio (measured / calculated) ${ }^{\mathrm{c}}$ & 0.54 & 0.52 & 6.2 & 0.18 & 0.73 \\
\hline
\end{tabular}

${ }^{a}$ Sediment data from Skalnate Pleso were not available. Sedimentation rates from two nearby lakes in the Tatra Mountains are shown for comparison. ${ }^{\mathrm{b}}$ Calculated considering that all atmospheric inputs in the lake and its catchment area accumulate in the lake sediments (atmospheric deposition $\times$ catchment area)/lake area. ${ }^{\mathrm{c}}$ Ratio between measured sediment fluxes and those calculated from the atmospheric deposition considering the lake and its catchment area.

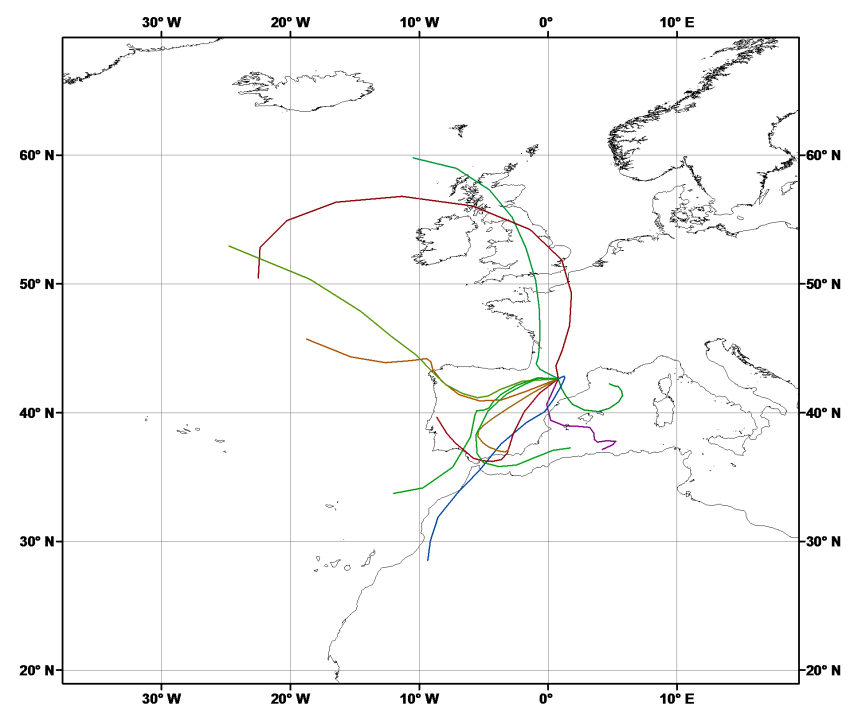

Figure 3. Prevalent back trajectories in Redon from 1 to 29 June 2006, mainly originating from southern areas.

position showed a positive correlation with air masses from central and eastern Europe (Table 5).

The two main air mass trajectories arriving at Redon are clearly different in terms of meteorological characteristics and PAH deposition fluxes. As reported elsewhere, backwards air mass trajectories in Redon showed a well-defined seasonal pattern (Arellano et al., 2014). Southern trajectories were dominant during the warm season (June-October; $59 \%$; see Fig. 3 as an example), while North Atlantic trajectories prevailed during cold periods (November-May; $48 \%$ ). The central and eastern European trajectories identified in this site were less frequent and did not show any seasonal trend.
Southern air masses in this site are characterised by high temperature and particle content (positive correlation with $T$ and particle deposition flows, Table 5), which is consistent with Saharan dust inputs and the well-known geographical characteristics of the northern African regions. In this case, a significant negative association was observed between particle-normalised PAH flows and air masses from this origin, mainly for the LMW-PAHs (Table 5), which may respond to both a gas-phase-aerosol displacement towards the former and a low PAH content of the Saharan dust in comparison to the PAH concentrations in particles from other areas. Despite this, the overall result is an increase in PAH loads to Redon during the warm periods due to the high amount of particles arriving at this site in spring-summer (Table 1). Air masses originating from the North Atlantic involved higher precipitation and lower particle content (significant positive and negative correlation with these variables respectively). Particle-normalised PAH fallout was positively correlated with air masses of this origin (Table 5), which was consistent with the dependence of PAH deposition on precipitation at this site (Table 4), likely enhanced by gas phase-aerosol partitioning of PAHs at low temperatures and increased scavenging efficiency of snow compared to rain (Fernandez et al., 2002; Arellano et al., 2011). Finally, air masses from central and eastern Europe are negatively correlated with PAH deposition fluxes, mainly for HMW-PAHs (Table 5). Air masses from this origin were therefore not significant for PAH fallout.

\subsection{Atmospheric PAH deposition and lacustrine sedimentary fluxes}

The atmospheric deposition samplers are located close to high mountain lakes. Previous studies of sediment cores in these lakes allowed the average PAH sediment 
fluxes to be determined in the top cores from Redon and Gossenköllesee, 120 and $125 \mu \mathrm{g} \mathrm{m}^{-2} \mathrm{yr}^{-1}$ respectively (Fernandez et al., 1999). The sedimentation flux in Lochnagar was calculated from the PAH concentrations (4000 $\mathrm{ng} \mathrm{g}^{-1} \mathrm{dw}$; data not published) using a sedimentation rate of $0.012 \mathrm{~g} \mathrm{~cm}^{-2} \mathrm{yr}^{-1}$ (Rose, 2001), which resulted in a PAH flux of $480 \mu \mathrm{g} \mathrm{m}^{-2} \mathrm{yr}^{-1}$. No lake sediment was available for Skalnate Pleso. Therefore, PAH fluxes from two nearby lakes in the Tatra Mountains were considered, e.g. Starolesnianske Pleso with $3000 \mu \mathrm{g} \mathrm{m}^{-2} \mathrm{yr}^{-1}$ (Fernandez et al., 1999) and Ladove Pleso with $1400 \mu \mathrm{g} \mathrm{m}^{-2} \mathrm{yr}^{-1}$ (Drooge et al., 2011).

Comparison of the PAH atmospheric deposition and lacustrine sedimentary fluxes showed much higher values in sediments, i.e. $24-100$ and $120-3000 \mu \mathrm{g} \mathrm{m}^{-2} \mathrm{yr}^{-1}$ respectively (Table 6). All lakes considered in this comparison are located in high mountain areas and their hydrological regime is determined by atmospheric precipitation into the watershed. The strong difference in flux values of the direct PAH atmospheric and sedimentary measurements may respond to processes such as the sediment focusing (Rowan et al., 1995) or lake sediment concentration of these hydrocarbons falling into the surface of the lake catchment. Studies at low altitude (seawater) have reported that air-water exchange is the most important process for low molecular weight PAH inputs into aquatic systems, exceeding the wet and dry deposition (Tsapakis et al., 2006; Ruge et al., 2015). In these high mountain lakes, the average concentrations of volatile PAHs are lower than in low-altitude aquatic systems, e.g. air and water concentrations of phenanthrene $0.99 \mathrm{ng} \mathrm{m}^{-3}$ (Fernandez et al., 2003; van Drooge et al., 2010) and $180 \mathrm{ng} \mathrm{m}^{-3}$ (Vilanova et al., 2001) respectively vs. $3.3-16$ and $450-5600 \mathrm{ng} \mathrm{m}^{-3}$ in marine systems (Gigliotti et al., 2002; Tsapakis et al., 2006). The smaller concentrations in high mountains should involve lower gas-water transfer gradients (Nelson et al., 1998). Irrespective of these values, flux calculations in some of these high mountain lakes for compounds with properties similar to those of PAH showed that the main transfer essentially occurs from water to air (Meijer et al., 2009). The overall mass balance involved pollutant incorporation into the lake waters due to atmospheric precipitation and a substantial degassing to the atmosphere. Thus, in these lakes the air-water transfer processes cannot explain the higher sedimentation fluxes in comparison to atmospheric precipitation.

Regarding the contributions of PAH inputs from the watershed, an estimated sediment flux was calculated considering that the total amount of atmospheric PAHs deposited in the lake and its catchment area were accumulated in the lake sediments (Table 6). Interestingly, in the case of Lochnagar, Redon and Ladove, the ratio between calculated and measured sediment fluxes varied between 0.5 and 0.7. This consistency between atmospheric and sedimentary PAHs in high-altitude areas situated in different areas of Europe is remarkable, taking into account that it has been considered that sediment area equals lake area, and confirms the predominant

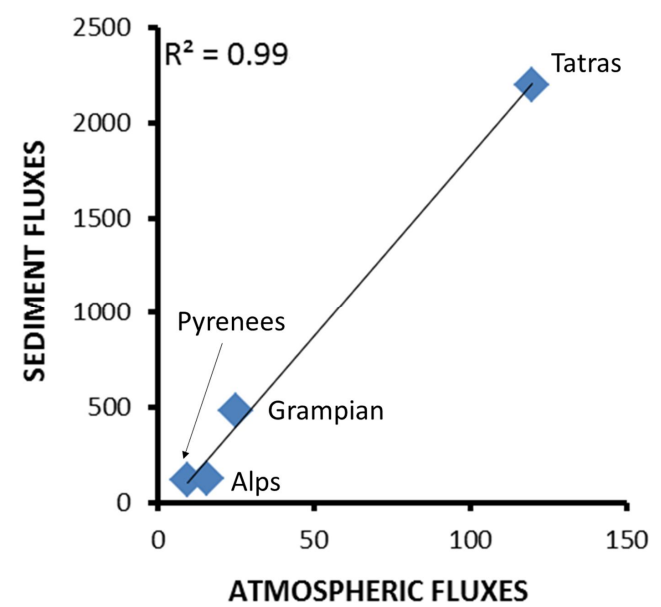

Figure 4. Average PAH sediment and atmospheric deposition fluxes at the high-altitude lakes considered in this study. Units in $\mu \mathrm{g} \mathrm{m} \mathrm{mr}^{-1}$.

atmospheric PAH origin in all studied sites. In Gossenköllesee, calculated sediment fluxes are 6-fold higher than measured values, which indicates that a small fraction of the PAHs deposited in the lake watershed accumulate in the surface sediments. On the contrary, calculated sediment fluxes in Starolesnianske Pleso are 1 order of magnitude lower than measured fluxes. The difference between Ladove and Starolesnianske Pleso, both situated in the same region could be related to orographic and hydrological characteristics of the latter that enhanced the PAH inputs and accumulation in Staroleniasnke Pleso sediments. This would explain the high concentration of PAHs found in this site in comparison with other lakes from the same area (Fernández et al., 1999, 2000). Another possibility for these differences could be related to a decrease in PAH atmospheric concentrations in this region during the last decades. Atmospheric deposition fluxes were measured between 2004 and 2006, whereas sedimentary fluxes correspond to 2001 in Ladove, but 10 years before in the case of Starolesnianske Pleso (1991).

Representation of the PAH sedimentary settling fluxes and average atmospheric deposition from each high mountain site showed a strong significant correlation $\left(R^{2}=0.99 ; p<0.01\right.$; Fig. 4). The standardised residual of this correlation fulfilled the normality conditions according to the Shapiro-Wilk test. Representation of the same data set excluding the area of highest PAH deposition, High Tatras, also showed a strong correlation $\left(R^{2}=0.86 ; p<0.20\right)$ but in this case there was no statistical significance given the small statistical freedom resulting from the number of cases considered. In any case, the values of both data sets (Table 6) followed parallel distributions. 


\section{Summary and conclusions}

The PAH and benzo[a]pyrene deposition fluxes recorded in the studied high mountain areas of Europe (790$2413 \mathrm{~m}$ ) range among the lowest described in remote, rural, coastal, suburban, urban or industrial areas. Nevertheless, a strong contrast is observed between the PAH deposition fluxes in Lochnagar, Gossenköllesee and Redon, $0.80-2.1 \mu \mathrm{g} \mathrm{m}^{-2}$ month $^{-1}$, and Skalnate Pleso, $9.7 \mu \mathrm{g} \mathrm{m}^{-2}$ month $^{-1}$, the latter showing PAH deposition fluxes between 5 and 10 times higher than the others, likely as a consequence of inputs from southern Poland and other areas.

Low molecular weight compounds from acenaphthene to pyrene dominate the atmospheric deposition of PAHs, with phenanthrene, fluoranthene and pyrene representing $32 \%-$ $60 \%$ of the total. The proportion of phenanthrene, the most abundant compound in the PAH distribution of each sample was higher at the sites of lower temperature, Gossenköllesee and Skalnate Pleso, indicating higher transfer from gas phase to particles of the more volatile PAHs.

Insolation was another local property determining the deposited PAH distributions. The sites with lower insolation, e.g. those located at lower altitude, were those with a higher proportion of photooxidable compounds such as benz[a]anthracene.

Precipitation was the main driver of PAH fallout. However, when rain and snow deposition were low, particle settling also constituted an efficient driver for PAH deposition. Accordingly, in Redon and Lochnagar, the two sites receiving background long-range transported PAHs and highest precipitation, the fallout PAH fluxes were related to precipitation. Whereas no significant association was observed between long-range backward air trajectories and $\mathrm{PAH}$ deposition in Lochnagar, enhanced PAH fallout at higher precipitation essentially occurred for air masses originating from the North Atlantic in Redon. In these cases, particle-normalised PAH fallout was also associated with higher precipitation as these air masses were concurrent with lower temperatures, which enhanced gas to particle partitioning transfer. In the warm season (June-October), most of the air masses arriving at Redon originated from the south and particle deposition was enhanced as a consequence of Saharan inputs. In these cases, particle settling was also a driver of PAH deposition despite the low overall PAH content of the Saharan particles.

In Gossenköllesee, the site receiving lowest precipitation, PAH fallout was related to particle deposition, namely in the case of higher molecular weight homologues. No correlation was observed with precipitation and PAH deposition. However, the particle-normalised PAH deposition fluxes were significantly negatively correlated to temperature according to the transfer of these compounds from gas phase to particles at lower temperatures, which enhanced PAH fallout, mainly for the most volatile hydrocarbons. These dependences were observed to occur when air masses originated from central and eastern Europe. Lower deposition of total particles and PAHs were observed in this site for air masses originating from the north.

Comparison of PAH atmospheric deposition and lacustrine sedimentary fluxes showed much higher values for the latter, 24-100 $\mu \mathrm{g} \mathrm{m}^{-2} \mathrm{yr}^{-1}$ compared with $120-3000 \mu \mathrm{g} \mathrm{m}^{-2} \mathrm{yr}^{-1}$ respectively. However, the representation of the PAH settling fluxes and average atmospheric deposition at each site showed a strong significant correlation. Moreover, estimated sediment fluxes calculated from the PAH atmospheric deposition measured in each site, taking into account inputs from the lake catchment, showed slightly lower values than measured fluxes, which indicates that the PAHs accumulated in the lacustrine sediments of high mountains reflect the atmospheric fallout of these hydrocarbons.

Data availability. The PAH deposition data are available from the public repository digital.CSIC (http://hdl.handle.net/10261/171874, Arellano et al., 2018).

Author contributions. LA carried out sample processing and OC analysis of the samples taken between 2004 and 2007 and performed the backward air mass trajectory calculations. Sampling and other field work were designed and performed at each site by NLR (Lochnagar), UN and HT (Gossenköllesee), ES (Skalnaté), and LC (Redón). PF performed the data interpretation and prepared the paper with contributions from all co-authors, especially JOG.

Competing interests. The authors declare that they have no conflict of interest.

Acknowledgements. This paper is dedicated to the memory of the mountain guides Unai Pérez de Arenaza and Gaspar Giner-Abati, who lost their lives because of an avalanche that occurred when they were accompanying a scientific expedition to take samples in Lake Redon (Pyrenees, 22 March 2018), and to Rober Sánchez, who was seriously injured. We thank Patricia Alabart, Roser Chaler, Dori Fanjul, and María Comesaña for their technical assistance in GC and GC-MS analysis. We also thank the meteorological observatory in Skalnate Pleso (Division of Geophysics, Earth Science Institute of Slovak Academy of Science) for providing of working facilities, help with sampling and for meteorological data. Financial support was provided by the CUANTOX (CTM2015-71832-P) and GRACCIE-REDES (CTM2014-59111-REDC) projects from the Spanish Ministry of Economy and Competitiveness and the EU project EUROLIMPACS (GOCE-CT-2003-505540). Lourdes Arellano is thankful for a grant provided jointly by Banco Santander Central Hispano.

Edited by: Kimitaka Kawamura

Reviewed by: two anonymous referees 


\section{References}

Arellano, L., Fernández, P., Tatosova, J., Stuchlik, E., and Grimalt, J. O.: Long-Range Transported Atmospheric Pollutants in Snowpacks Accumulated at Different Altitudes in the Tatra Mountains (Slovakia), Environ. Sci. Technol., 45, 9268-9275, https://doi.org/10.1021/es202111n, 2011.

Arellano, L., Fernández, P., López, J. F., Rose, N. L., Nickus, U., Thies, H. J., Stuchlik, E., Camarero, L., Catalan, J., and Grimalt, J. O.: Atmospheric deposition of polybromodiphenyl ethers in remote mountain regions of Europe, Atmos. Chem. Phys., 14, 4441-4457, https://doi.org/10.5194/acp-14-4441-2014, 2014.

Arellano, L., Fernández, P., Fonts, R., Rose, N. L., Nickus, U., Thies, H. J., Stuchlik, E., Camarero, L., Catalan, J., and Grimalt, J. O.: Increasing and Decreasing Trends of the Atmospheric Deposition of Organochlorine Compounds in European Remote Areas during the Last Decade, Atmos. Chem. Phys., 15, 60696085, https://doi.org/10.5194/acp-15-6069-2015, 2015.

Arellano, L., Fernández, P., and Grimalt, J. O.: PAH Atmospheric Deposition in High Mountain Lakes, available at: http://hdl. handle.net/10261/171874, last access: 6 November 2018.

Armstrong, B., Hutchinson, E., Unwin, J., and Fletcher, T.: Lung Cancer Risk after Exposure to Polycyclic Aromatic Hydroarbons: A review and Meta-Analysis, Environ. Health Persp., 112, 970-978, https://doi.org/10.1289/ehp.6895, 2004.

Bae, S.Y., Yi, S. M., and Kim, Y. P.: Temporal and spatial variations of the particle size distribution of PAHs and their dry deposition fluxes in Korea, Atmos. Environ., 36, 5461-5500, https://doi.org/10.1016/S1352-2310(02)00666-0, 2002.

Baek, S. O., Field, R. A., Goldstone, M. E., Kirk, P. W., Lester, J. N., and Perry, R.: A review of atmospheric polycyclic hydrocarbons: sources, fate and behaviour, Water Air Soil Poll., 60, 279-300, https://doi.org/10.1007/BF00282628, 1991.

Bari, M. A., Kindzierski, W. B., and Cho, S.: A wintertime investigation of atmospheric deposition of metals and polycyclic aromatic hydrocarbons in the Athabasca Oil Sands Region, Canada, Sci. Total Environ., 485, 180-192, https://doi.org/10.1016/j.scitotenv.2014.03.088, 2014.

Behymer, T. D. and Hites, R. A.: Photolysis of polycyclic aromatic hydrocarbons adsorbed on fly ash, Environ. Sci. Technol., 22, 1311-1319, https://doi.org/10.1021/es00176a011, 1988.

Birgul, A., Tasdemir, Y., and Cindoruk, S. S.: Atmospheric wet and dry deposition of polycyclic aromatic hydrocarbons (PAHs) determined using a modified sampler, Atmos. Res., 101, 341-353, https://doi.org/10.1016/j.atmosres.2011.03.012, 2011.

Brorström-Lundén, E., and Löfgren, C.: Atmospheric fluxes of persistent semivolatile organic pollutants to a forest ecological system at the Swedish west coast and accumulation in spruce needles, Environ. Poll., 102, 139-149, https://doi.org/10.1016/S0269-7491(98)00081-5, 1998.

Brun, G. L., Vaidya, O. C., and Léger, M. G.: Atmospheric Deposition of Polycyclic Aromatic Hydrocarbons to Atlantic Canada: Geographic and Temporal Distributions and Trends 1980-2001, Environ. Sci. Technol., 38, 1941-1948, https://doi.org/10.1021/es0346451, 2004.

Carrera, G., Fernández, P., Vilanova, R., and Grimalt, J. O.: Analysis of Trace Polycyclic Aromatic Hydrocarbons and Organochlorine Compounds in Atmospheric Residues by SolidPhase Disk Extraction, J. Chromatogr. A, 823, 189-196, https://doi.org/10.1016/S0021-9673(98)00519-6, 1998.
Cetin, B., Odabasi, M., and Bayram, A.: Wet deposition of persistent organic pollutants (POPs) in Izmir, Turkey, Environ. Sci. Poll. Res., 23, 9227-9236, https://doi.org/10.1007/s11356-0166183-6, 2016.

Ding, X., Wang, X. M., Xie, Z. O., Xiang, C. H., Mai, B. X., Sun, L. G., Zheng, M., Sheng, G. Y., Fu, J. M., and Pöschl, U.: Atmospheric polycyclic aromatic hydrocarbons observed over the North Pacific Ocean and the Arctic area: Spatial distribution and source identification, Atmos. Environ., 41, 2061-2072, https://doi.org/10.1016/j.atmosenv.2006.11.002, 2007.

Draxler, R. R. and Hess, G. D.: An overview of the HYSPLIT_4 modelling system for trajectories, dispersion, and deposition, Aust. Meteorol. Mag., 47, 295-308, 1998.

Esen, F., Siddik Cindoruk, S., and Tasdemir, Y.: Bulk deposition of polycyclic aromatic hydrocarbons (PAHs) in an industrial site of Turkey, Environ. Poll., 152, 461-467, https://doi.org/10.1016/j.envpol.2007.05.031, 2008.

Fang, G. C., Chang, K. F., Lu, C., and Bai, H.: Estimation of PAHs dry deposition and $\mathrm{BaP}$ toxic equivalency factors (TEFs) study at urban, industry Park and rural sampling sites in Central Taiwan, Taichung, Chemosphere, 55, 787-796, https://doi.org/10.1016/j.chemosphere.2003.12.012, 2004.

Feng, D., Liu, Y., Gao, Y., Zhou, J., Zheng, L., Qiao, G., Ma, L., Lin, Z., and Grathwohl, P.: Atmospheric bulk deposition of polycyclic aromatic hydrocarbons in Shanghai: Temporal and spatial variation, and global comparison, Environ. Poll., 230, 639-647, https://doi.org/10.1016/j.envpol.2017.07.022, 2017.

Fernández, P., Vilanova, R. M., and Grimalt, J. O.: Sediment Fluxes of Polycyclic Aromatic Hydrocarbons in European High Altitude Mountain Lakes, Environ. Sci. Technol., 33, 3716-3722, https://doi.org/10.1021/es9904639, 1999.

Fernández, P., Vilanova, R. M., Martínez, C., Appleby, P., and Grimalt, J. O.: The Historical Record of Atmospheric Pyrolitic Pollution over Europe Registered in the Sedimentary PAH from Remote Mountain Lakes, Environ. Sci. Technol., 34, 1906-1913, https://doi.org/10.1021/es9912271, 2000.

Fernández, P., Grimalt, J. O., and Vilanova, R. M.: Atmospheric Gas-Particle Partitioning of Polycyclic Aromatic Hydrocarbons in High Mountain Regions of Europe, Environ. Sci. Technol., 36, 1162-1168, https://doi.org/10.1021/es010190t, 2002.

Fernández, P., Carrera, G., Grimalt, J. O., Ventura, M., Camarero, L., Catalán, J., Nickus, U., Thies, H., and Psenner, R.: Factors Governing the Atmospheric Deposition of Polycyclic Aromatic Hydrocarbons to Remote Areas, Environ. Sci. Technol., 37, 3261-3267, https://doi.org/10.1021/es020137k, 2003.

Foan, L., Domerq, M., Bermejo, R., M. Santamaria, J., and Simon, V.: Polycyclic Aromatic Hydrocarbons (PAHs) in Remote Bulk and Throughfall deposition: Seasonal and Spatial Trends, Environ. Eng. Manag. J., 11, 1101-1110, https://doi.org/10.30638/eemj.2012.134, 2012.

Gaga, E. O., Tuncel, G., and Tuncel, S. G.: Sources and Wet Deposition Fluxes of Polycyclic Aromatic Hydrocarbons (PAHs) in an Urban Site 1000 Meters High in Central Anatolia (Turkey), Environ. Forensics, 10, 286-298, https://doi.org/10.1080/15275920903347594, 2009.

Garban, B., Blanchoud, H., Motelay-Massei, A., Chevreuil, M., and Ollivon, D.: Atmospheric bulk deposition of PAHs onto France: trends from urban to remote sites, Atmos. Environ., 36, 53955403, https://doi.org/10.1016/S1352-2310(02)00414-4, 2002. 
Gigliotti, C. L., Totten, L. A., Offenberg, J. H., Dachs, J., Reinfelder, J. R., Nelson, E. D., Glenn, T. R., and Eisenreich, S. J.: Atmospheric concentrations and deposition of polycyclic aromatic hydrocarbons to the Mid-Atlantic East Coast Region, Environ. Sci. Technol., 39, 5550-5559, https://doi.org/10.1021/es050401k, 2005.

Gocht, T., Klemm, O., and Grathwohl, P.: Long-term atmospheric bulk deposition of polycyclic aromatic hydrocarbons (PAHs) in rural areas of Southern Germany, Atmos. Environ., 41, 13151327, https://doi.org/10.1016/j.atmosenv.2006.09.036, 2007.

Golomb, D., Barry, E., Fisher, G., Varanusupakul, P., Koleda, M., and Rooney, T.: Atmospheric deposition of polycyclic aromatic hydrocarbons near New England coastal waters, Atmos. Environ., 35, 6245-6258, https://doi.org/10.1016/S13522310(01)00456-3, 2001.

Grimalt, J. O., Fernández, P., Berdié, L., Vilanova, R. M., Catalan, J., Psenner, R., Hofer, R., Appleby, P. G., Lien, L., Rosseland, B. O., Massabuau, J.-C., and Battarbee, R. W.: Selective Trapping of Organochlorine Compounds in Mountain Lakes of Temperate Areas, Environ. Sci. Technol., 35, 2690-2697, https://doi.org/10.1021/es000278r, 2001.

Grimalt, J. O., van Drooge, B. L., Ribes, A., Fernández, P., and Appleby, P.: Polycyclic aromatic hydrocarbon composition in soils and sediments of high altitude lakes, Environ. Poll., 131, 13-24, https://doi.org/10.1016/j.envpol.2004.02.024, 2004.

Gustafson, K. E. and Dickhut, R. M.: Particle/Gas Concentrations and Distributions of PAHs in the Atmosphere of Southern Chesapeake Bay, Environ. Sci. Technol., 31, 140-147, https://doi.org/10.1021/es9602197, 1997.

Halsall, C. J., Coleman, P. J., and Jones, K. C.: Atmospheric deposition of polychlorinated dibenzo-p-dioxins/dibenzofurans (PCDD/Fs) and polycyclic aromatic hydrocarbons (PAHs) in two UK cities, Chemosphere, 35, 1919-1931, https://doi.org/10.1016/S0045-6535(97)00265-8, 1997.

Halsall, C. J., Sweetman, A. J., Barrie, L. A., and Jones, K. C.: Modelling the behaviour of PAHs during atmospheric transport from the UK to the Arctic, Atmos. Environ., 35, 255-267, https://doi.org/10.1016/S1352-2310(00)00195-3, 2001

Holoubek, I., Klánová, J., Jarkovský, J., and Kohoutek, J.: Trends in background levels of persistent organic pollutants at Kosetice observatory, Czech Republic. Part I. Ambient air and wet deposition 1996-2005, J. Environ. Monitor., 9, 557-563, https://doi.org/10.1039/B700750G, 2007.

Horstmann, M. and McLachlan, M. S.: Atmospheric deposition of semivolatile organic compounds to two forest canopies, Atmos. Environ., 32, 1799-1809, https://doi.org/10.1016/S13522310(97)00477-9, 1998

HYSPLIT (HYbrid Single-Particle Lagrangian Integrated Trajectory): Model access via NOAA ARL READY, available at: http: //ready.arl.noaa.gov/HYSPLIT.php, 2013.

Jaward, F. M., Farrar, N. J., Harner, T., Sweetman, A. J., and Jones, K. C.: Passive air sampling of polycyclic aromatic hydrocarbons and polychlorinated naphthalenes across Europe, Environ. Toxicol. Chem., 23, 1355-1364, https://doi.org/10.1897/03-420, 2004.

Kirchgeorg, T., Dreyer, A., Gabrielli, P., Gabrieli, J., Thompson, L. G., Barbante, C., and Ebinghaus, R.: Seasonal accumulation of persistent organic pollutants on a high altitude glacier in the Eastern Alps, Environ. Poll., 218, 804-812, https://doi.org/10.1016/j.envpol.2016.08.004, 2016

Kiss, G., Varga-Puchony, Z., Tolnai, B., Varga, B., Gelencsér, A., Krivácsy, Z., and Hlavay, J.: The seasonal changes in the concentration of polycyclic aromatic hydrocarbons in precipitation and aerosol near Lake Balaton, Hungary, Environ. Poll., 114, 55-61, https://doi.org/10.1016/S0269-7491(00)00208-6, 2001.

Leister, D. L. and Baker, J. E.: Atmospheric deposition of organic contaminants to the Chesepeake Bay, Atmos. Environ., 28, 1499-1520, https://doi.org/10.1016/1352-2310(94)90210-0, 1994.

Li, J., Cheng, H., Zhang, G., Qi, S., and Li, X.: Polycyclic aromatic hydrocarbon (PAH) deposition to and exchange at the air-water interface of Luhu, an urban lake in Guangzhou, China, Environ. Poll., 157, 273-279, https://doi.org/10.1016/j.envpol.2008.06.039, 2009.

Li, P.-H., Wang, Y., Li, Y.-H., Wang, Z.-f., Zhang, H.-Y., Xu, P.-J., and Wang, W.-X.: Characterization of polycyclic aromatic hydrocarbons deposition in $\mathrm{PM}_{2.5}$ and cloud/fog water at Mount Taishan (China), Atmos. Environ., 44, 1996-2003, https://doi.org/10.1016/j.atmosenv.2010.02.031, 2010.

Li, P.-H., Wang, Y., Li, Y.-H., Wai, K.-M., Li, H.-L., and Tong, L.: Gas-particle partitioning and precipitation scavenging of polycyclic aromatic hydrocarbons (PAHs) in the free troposphere in southern China, Atmos. Environ., 128, 165-174, https://doi.org/10.1016/j.atmosenv.2015.12.030, 2016.

Lipiatou, E., Tolosa, I., Simo, R., Bouloubassi, I., Dachs, J., Marti, S., Sicre, M. A., Bayona, J. M., Grimalt, J. O., Saliot, A., and Albaiges, J.: Mass budget and dynamics of polycyclic aromatic hydrocarbons in the Mediterranean Sea, Deep-Sea Res. Pt II, 4, 881-905, https://doi.org/10.1016/S0967-0645(96)00093-8, 1997.

Ma, J. and Cao, Z.: Quantifying the Perturbations of Persistent Organic Pollutants Induced by Climate Change, Environ. Sci. Technol., 44, 8567-8573, https://doi.org/10.1021/es101771g, 2010.

Ma, J., Hung, H., Tian, C., and Kallenborn, R.: Revolatilization of persistent organic pollutants in the Arctic induced by climate change, Nat. Clim. Change, 1, 255-260, https://doi.org/10.1038/nclimate1167, 2011.

Ma, Y., Xie, Z., Yang, H., Moeller, A., Halsall, C., Cai, M., Sturm, R., and Ebinghaus, R.: Deposition of polycyclic aromatic hydrocarbons in the North Pacific and the Arctic, J. Geophys. Res.Atmos., 118, 5822, https://doi.org/10.1002/jgrd.50473, 2013.

McVeety, B. D. and Hites, R. A.: Atmospheric deposition of polycyclic aromatic hydrocarbons to water surfaces: A mass balance approach, Atmos. Environ., 22, 511-536, https://doi.org/10.1016/0004-6981(88)90196-5, 1988.

Meijer, S. N., Sweetman, A. J., Halsall, C. J., and Jones, K. C.: Temporal Trends of Polycyclic Aromatic Hydrocarbons in the U.K. Atmosphere: 1991-2005, Environ. Sci. Technol., 42, 32133218, https://doi.org/10.1021/es702979d, 2008.

Meijer, S. N., Grimalt, J. O., Fernández, P., and Dach, J.: Seasonal fluxes and temperature-dependent accumulation of persistent organic pollutants in lakes: The role of internal biogeochemical cycling, Environ. Poll., 157, 1815-1822, https://doi.org/10.1016/j.envpol.2009.01.024, 2009.

Menichini, E., Barbera, S., Merli, F., Settimo, G., and Viviano, G.: Atmospheric bulk deposition of carcinogenic PAHs in a 
rural area in Southern Italy, Pol. Arom. Comp., 26, 253-263, https://doi.org/10.1080/10406630600904026, 2006.

Motelay-Massei, A., Ollivon, D., Garban, B., and Chevreuil, M.: Polycylic aromatic hydrocarbons in bulk deposition at a suburban site: assessment by principal component analysis of the influence of meteorological parameters, Atmos. Environ., 37, 3135-3146, https://doi.org/10.1016/S1352-2310(03)00218-8, 2003.

Nelson, E. D., McConnell, L. L., and Baker, J. E.: Diffusive exchange of gaseous polycyclic aromatic hydrocarbons and polychlorinated biphenyls across the air-water interface of the Chesapeake Bay, Environ. Sci. Technol., 32, 912-919, https://doi.org/10.1021/es9706155, 1998.

Offenthaler, I., Jakobi, G., Kaiser, A., Kirchner, M., Kräuchi, N., Niedermoser, B., Schramm, K. W., Sedivy, I., Staudinger, M., Thanner, G., Weiss, P., and Moche, W.: Novel sampling methods for atmospheric semi-volatile organic compounds (SOCs) in a high altitude alpine environment, Environ. Poll., 157, 32903297, https://doi.org/10.1016/j.envpol.2009.05.053, 2009.

Ollivon, D., Blanchoud, H., Motelay-Massei, A., and Garban, B.: Atmospheric deposition of PAHs to an urban site, Paris, France, Atmos. Environ., 36, 2891-2900, https://doi.org/10.1016/S13522310(02)00089-4, 2002.

Pacyna, J. M., Breivik, K., Münch, J., and Fudala, J.: European Atmospheric Emissions of Selected Persistent Organic Pollutants, 1970-1995, Atmos. Environ., 37, S119-S131, https://doi.org/10.1016/S1352-2310(03)00240-1, 2003.

Park, J.-S., Wade, T. L., and Sweet, S.: Atmospheric distribution of polycyclic aromatic hydrocarbons and deposition to Galveston Bay, Texas, USA, Atmos. Environ., 35, 3241-3249, https://doi.org/10.1016/S1352-2310(01)00080-2, 2001.

Pekey, B., Karakas, D., and Ayberk, S.: Atmospheric deposition of polycyclic aromatic hydrocarbons to Izmit Bay, Turkey, Chemosphere, 67, 537-547, https://doi.org/10.1016/j.chemosphere.2006.09.054, 2007.

Poor, N., Tremblay, R., Kay, H., Bhethanabotla, V., Swartz, E., Luther, M., and Campbell, S.: Atmospheric concentrations and dry deposition rates of polycyclic aromatic hydrocarbons (PAHs) for Tampa Bay, Florida, USA, Atmos. Environ., 38, 6005-6015, https://doi.org/10.1016/j.atmosenv.2004.06.037, 2004.

Rose, N. L.: An Historical Record of Toxaphene and Its Congeners in a Remote Lake in Western Europe, Environ. Sci. Technol., 35, 1312, https://doi.org/10.1021/es0015895, 2001.

Rowan, D. J., Cornett, R. J., King, K., and Risto, B.: Sediment focusing and ${ }^{210} \mathrm{~Pb}$ dating: a new approach, J. Paleolimnol., 13, 107-118, https://doi.org/10.1007/BF00678101, 1995.

Ruge, Z., Muir, D., Helm, P., and Lohmann, R.: Concentrations, Trends, and Air-Water Exchange of PAHs and PBDEs Derived from Passive Samplers in Lake Superior in 2011, Environ. Sci. Technol., 49, 13777-13786, https://doi.org/10.1021/acs.est.5b02611, 2015.

Schifman, L. A. and Boving, T. B.: Spatial and seasonal atmospheric PAH deposition patterns and sources in Rhode Island, Atmos. Environ., 120, 253-261, https://doi.org/10.1016/j.atmosenv.2015.08.056, 2015.

Shahpoury, P., Lammel, G., Smejkalova, A. H., Klánová, J., Pribylova, P., and Vana, M.: Polycyclic aromatic hydrocarbons, polychlorinated biphenyls, and chlorinated pesticides in background air in central Europe - investigating parameters affecting wet scavenging of polycyclic aromatic hydrocarbons, At- mos. Chem. Phys., 15, 1795-1805, https://doi.org/10.5194/acp15-1795-2015, 2015.

Sharma, B. M., Melymuk, L., Bharat, G. K., Přibylová, P., Sáňka, O., Klánová, J., and Nizzetto, L.: Spatial gradients of polycyclic aromatic hydrocarbons (PAHs) in air, atmospheric deposition, and surface water of the Ganges River basin, Sci. Total Environ., 627, 1495-1504, https://doi.org/10.1016/j.scitotenv.2018.01.262, 2018.

Sicre, M. A., Marty, J. C., Saliot, A., Aparicio, X., Grimalt, J. O., and Albaigés, J.: Aliphatic and aromatic hydrocarbons in different sized aerosols over the Mediterranean Sea: Occurrence and Origin, Atmos. Environ. 21, 2247-2259, https://doi.org/10.1016/0004-6981(87)90356-8, 1987

Simcik, M. F., Franz, T. P., Zhang, H., and Eisenreich, S. J.: Gasparticle partitioning of PCBs and PAHs in the Chicago urban and adjacent coastal atmosphere: states of equilibrium, Environ. Sci. Technol., 32, 251-257, https://doi.org/10.1021/es970557n, 1998.

Singh, D. K., Kawamura, K., Yanase, A., and Barrie, L. A.: Distributions of Polycyclic Aromatic Hydrocarbons, Aromatic Ketones, Carboxylic Acids, and Trace Metals in Arctic Aerosols: Long-Range Atmospheric Transport, Photochemical Degradation/Production at Polar Sunrise, Environ. Sci. Technol., 51, 8992-9004, https://doi.org/10.1021/acs.est.7b01644, 2017.

Su, Y., Wania, F., Harner, T., and Lei, Y. D.: Deposition of polybrominated diphenyl ethers, polychlorinated biphenyls, and polycyclic aromatic hydrocarbons to a boreal deciduous forest, Environ. Sci. Technol., 41, 534-540, https://doi.org/10.1021/es0622047, 2007.

Sun, P., Blanchard, P., Brice, K. A., and Hites, R. A.: Trends in Polycyclic Aromatic Hydrocarbon Concentrations in the Great Lakes Atmosphere, Environ. Sci. Technol., 40, 6221-6227, https://doi.org/10.1021/es0607279, 2006.

Terzi, E. and Samara, C.: Dry deposition of polycyclic aromatic hydrocarbons in urban and rural sites of Western Greece, Atmos. Environ., 39, 6261-6270, https://doi.org/10.1016/j.atmosenv.2005.06.057, 2005.

Torseth, K., Aas, W., Breivik, K., Fjaeraa, A. M., Fiebig, M., Hjellbrekke, A. G., Myhre, C. L., Solberg, S., and Yttri, K. E.: Introduction to the European Monitoring and Evaluation Programme (EMEP) and observed atmospheric composition change during 1972-2009, Atmos. Chem. Phys., 12, 5447-5481, https://doi.org/10.5194/acp-12-5447-2012, 2012.

Tsapakis, M., Apostolaki, M., Eisenreich, S., and Stephanou, E. G.: Atmospheric Deposition and Marine Sedimentation Fluxes of Polycyclic Aromatic Hydrocarbons in the Eastern Mediterranean Basin, Environ. Sci. Technol., 40, 4922-4927, https://doi.org/10.1021/es060487x, 2006.

Usenko, S., Simonich, S. L. M., Hageman, K. J., Schrlau, J. E., Geiser, L., Campbell, D. H., Appleby, P. G., and Landers, D. H.: Sources and Deposition of Polycyclic Aromatic Hydrocarbons to Western U.S. National Parks, Environ. Sci. Technol., 44, 45124518, https://doi.org/10.1021/es903844n, 2010.

van der Gong, H. D., Bolscher, M. V. H., Visschedijk, A., and Zandveld, P.: Emissions of persistent organic pollutants and eight candidate POPs from UNECE-Europe in 2000, 2010 and 2020 and the emission reduction resulting from the implementation of the UNECE POP protocol, Atmos. Environ., 41, 9245-9261, https://doi.org/10.1016/j.atmosenv.2007.06.055, 2007. 
van Drooge, B. L., López, J., Fernández, P., Grimalt, J. O., and Stuchlik, E.: Polycyclic aromatic hydrocarbons in lake sediments from the High Tatras, Environ. Poll., 159, 1234-1259, https://doi.org/10.1016/j.envpol.2011.01.035, 2011.

van Drooge, B. L., Fernández, P., Grimalt, J. O., Stuchlikk, E., Torres-García, C. J., and Cuevas, E.: Atmospheric polycyclic aromatic hydrocarbons in remote European and Atlantic sites located above the boundary mixing layer, Environ. Sci. Poll. Res., 17, 1207-1216, https://doi.org/10.1007/s11356-010-0296$0,2010$.

van Metre, P. C. and Mahler, B. J.: Trends in Hydrophobic Organic Contaminants in Urban and Reference Lake Sediments across the United States, 1970-2001, Environ. Sci. Technol., 39, 55675574, https://doi.org/10.1021/es0503175, 2005.

Venier, M., Salamova, A., and Hites, R. A.: Temporal trends of persistent organic pollutant concentrations in precipitation around the Great Lakes, Environ. Poll., 217, 143-148, https://doi.org/10.1016/j.envpol.2016.01.034, 2016.

Vilanova, R. M., Fernández, P., Martínez, C., and Grimalt, J. O.: Polycyclic aromatic hydrocarbons in remote mountain lake waters, Water Res., 35, 3916-3926, 2001.

Vives, I., Grimalt, J. O., Fernández, P., and Rosseland, B.: Polycyclic aromatic hydrocarbons in fish from remote and high mountian lakes in Europe and Greenland, Sci. Total Environ., 324, 67-77, https://doi.org/10.1016/j.scitotenv.2003.10.026, 2004.

Wang, W., Jariyasopit, N., Schrlau, J., Jia, Y., Tao, S., Yu, T.-W., Dashwood, R. H., Zhang, W., Wang, X., and Simonich, S. L. M.: Concentration and Photochemistry of PAHs, NPAHs, and OPAHs and Toxicity of $\mathrm{PM}_{2.5}$ during the Beijing Olympic Games, Environ. Sci. Technol., 45, 6887-6895, https://doi.org/10.1021/es201443z, 2011 a.
Wang, W., Simonich, S. L. M., Giri, B., Xue, M., Zhao, J., Chen, S., Shen, H., Shen, G., Wang, R., Cao, J., and Tao, S.: Spatial distribution and seasonal variation of atmospheric bulk deposition of polycyclic aromatic hydrocarbons in BeijingTianjin region, North China, Environ. Poll., 159, 287-293, https://doi.org/10.1016/j.envpol.2010.08.029, $2011 \mathrm{~b}$.

Wild, S. R. and Jones, K. C.: Polynuclear aromatic hydrocarbons in the United Kingdom environment: a preliminary source inventory and budget, Environ. Poll., 88, 91-108, https://doi.org/10.1016/0269-7491(95)91052-M, 1995.

Xing, X., Zhang, Y., Yang, D., Zhang, J., Chen, W., Wu, C., Liu, H., and Qi, S.: Spatio-temporal variations and influencing factors of polycyclic aromatic hydrocarbons in atmospheric bulk deposition along a plain-mountain transect in western China, Atmos. Environ., 139, 131-138, https://doi.org/10.1016/j.atmosenv.2016.05.027, 2016.

Yang, R., Xie, T., Li, A., Yang, H., Turner, S., Wu, G., and Jing, C.: Sedimentary records of polycyclic aromatic hydrocarbons (PAHs) in remote lakes across the Tibetan Plateau, Environ. Poll., 214, 1-7, https://doi.org/10.1016/j.envpol.2016.03.068, 2016.

Zhang, J., Yang, L., Mellouki, A., Chen, J., Chen, X., Gao, Y., Jiang, P., Li, Y., Yu, H., and Wang, W.: Atmospheric PAHs, NPAHs, and OPAHs at an urban, mountainous, and marine sites in Northern China: Molecular composition, sources, and ageing, Atmos. Environ., 173, 256-264, https://doi.org/10.1016/j.atmosenv.2017.11.002, 2018. 